\title{
Damir Tulić
}

Odsjek za povijest umjetnosti, Filozofski fakultet Sveučilišta u Rijeci

\section{Glory Crowned in Marble: Self-promotion of Individuals and Families in Seventeenth- and Eighteenth-Century Monuments in Istria and Dalmatia}

\author{
Original scientific paper - Izvorni znanstveni rad \\ Received - Primljen 7. 6. 2019. \\ UDK 725.94-032.5(497.571+497.58)"16/17" \\ DOI 10.31664/ripu.2019.43.11
}

\begin{abstract}
Senior representatives of the Venetian Republic inspired distinguished noblemen and rich citizens in Venice, as well as in Terraferma and Stato da Mar, to perpetuate their memory through lavish commemorative monuments that were erected in churches and convents. Their endeavour for self-promotion and their wish to monopolise glory could be detected in the choice of material for the busts that adorned almost every monument: marble. The most elaborate monument of this kind belongs to the Brutti family, erected in 1695 in Koper Cathedral. In 1688 the Town of Labin ordered a marble bust of local hero Antonio Bollani and placed it on the facade of the parish church. Fine examples of family glorification could be found in the capital of Venetian
\end{abstract}

Dalmatia - Zadar. In the Church of Saint Chrysogonus, there is a monument to the provveditore Marino Zorzi, adorned with a marble portrait bust. Rather similar is the monument to condottiere Simeone Fanfogna in Zadar's Benedictine Church of Saint Mary and the monument to the military engineer Francesco Rossini in Saint Simeon. All these monuments embellished with portrait busts have a common purpose: to ensure the everlasting memory of important individuals. This paper analyses comparative examples, models, artists, as well as the desires of clients or authorities that were able to invest money in self or family promotion, thus creating the identity of success.

Keywords: Dalmatia, Istria, Venice, public and funeral monuments, marble bust, stone sculpture, baroque

Erecting monuments with statues of public officers or important individuals has a long tradition in Venice. There are numerous richly decorated marble tombs and commemorative monuments dating to the $17^{\text {th }}$ and $18^{\text {th }}$ centuries in Venetian churches and on their façades. ${ }^{1}$ The most extraordinary dynastic family glorification, still visible on the façade of a Venetian church, is the one on Santa Maria del Giglio, designed by the architect Giuseppe Sardi in 1679. ${ }^{2}$ The capitano da mar Antonio Barbaro left 30,000 ducats for the new façade of the church, to be adorned with his statue and statues of his four brothers. ${ }^{3}$ Aside from Antonio Barbaro, who served the Serenissima in Zadar, Crete, Padua, Rome, Corfu and Split, without their lifesized marble statues placed on the lower part of the church façade his brothers Giovanni Maria, Marino, Francesco and Carlo would probably have been forgotten. ${ }^{4}$ These members of the Barbaro family immortalised themselves by replacing the statues of saints with their own, turning a religious façade into a profane one. Similarly, statues of public officers and military commanders were being erected all over Venetian territories. A very fine example of this tradition is the city- fortress of Palmanova, founded in $1597 .{ }^{5}$ On the main square there are ten life-sized marble statues of Provveditori, or army commanders, dressed in armour and with bastons in their hands symbolising their military leadership. ${ }^{6}$ The similar portraits of senior Venetian military and public officers in Dalmatia and Istria have been preserved only since the $17^{\text {th }}$ century. The high expenses connected to the erection of such lavish public monuments could explain their relatively late appearance, especially because the local town councils and provincial donors were used to stone commemorative inscriptions and coats of arms. Some orders by the Venetian Senate, particularly the one from the $15^{\text {th }}$ of December 1691 , strictly forbade making new commemorative inscriptions, coats of arms or statues of local Venetian officers and ordered the removal of the existing ones. ${ }^{7}$ It was believed that the merit of an individual could not be greater than the glory of the Republic itself. Many coats of arms, commemorative inscriptions and statues of town rectors and provveditores have been erased by chiselling. On the northern façade of the palace of the Provveditore Generale in Zadar still stands a decorative cartouche 


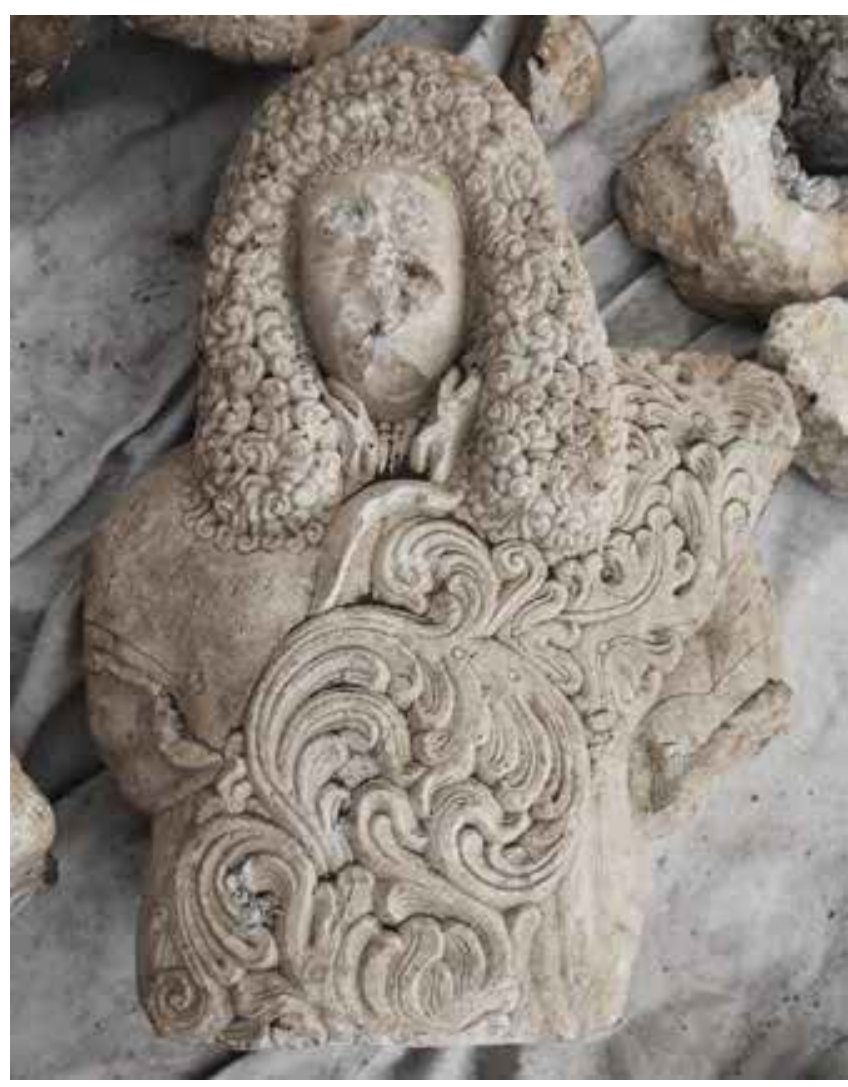

1. Venetian rector (Marco Lippomano ?), found during the archaeological excavation of the Tower of All Saints, Korčula (May, 2019)

Venecijanski knez (Marco Lippomano ?), pronađen prilikom arheoloških istraživanja kule Svih Svetih, Korčula (svibanj 2019.)

with an erased commemorative inscription, coat of arms and above it an empty round niche. ${ }^{8}$ A portrait bust of an unknown $17^{\text {th }}$ century provveditore once stood inside. In the spring of 2019 , during the archaeological excavations of the $15^{\text {th }}$-century All Saints Tower (Torrione Cappello) in the town of Korčula, two unknown stone busts emerged. ${ }^{9}$ The head of one of the statues has not been preserved, and the second statue has a disfigured face under a pompous late $17^{\text {th }}$-century wig and a richly decorated Venetian stole across the torso (Fig. 1). It is possible that this bust represents Marco Lippomano, who served as the rector of Korčula from 1681 until 1683. According to Giovanni Zorzi, the rector Lippomano's statue once stood inside the niche on the town walls near the maritime gate (Porta Marina) of Korčula. ${ }^{10}$

The oldest "portrait" bust of a senior Venetian officer in Dalmatia still standing is that of the provveditore generale Giangiacomo Zane, situated on the façade niche on the building of Vela straža (Gran guardia) in the main square in Zadar. The sculpture was made in 1608 by the master Tripun Bokanić from the island of Brač. ${ }^{11}$ On the façade of the Praetorian Palace in Koper a bronze bust of the doge Nicolò Donà still exists (Fig. 2). The original bust is now in the town's Regional Museum and its copy is placed above the main entrance into the palace. Thirty years before he was elected doge, Nicolò was a podestà in Koper. Unfortunately, he died in 1618, only thirty-three days after the election. The Koper Town Council

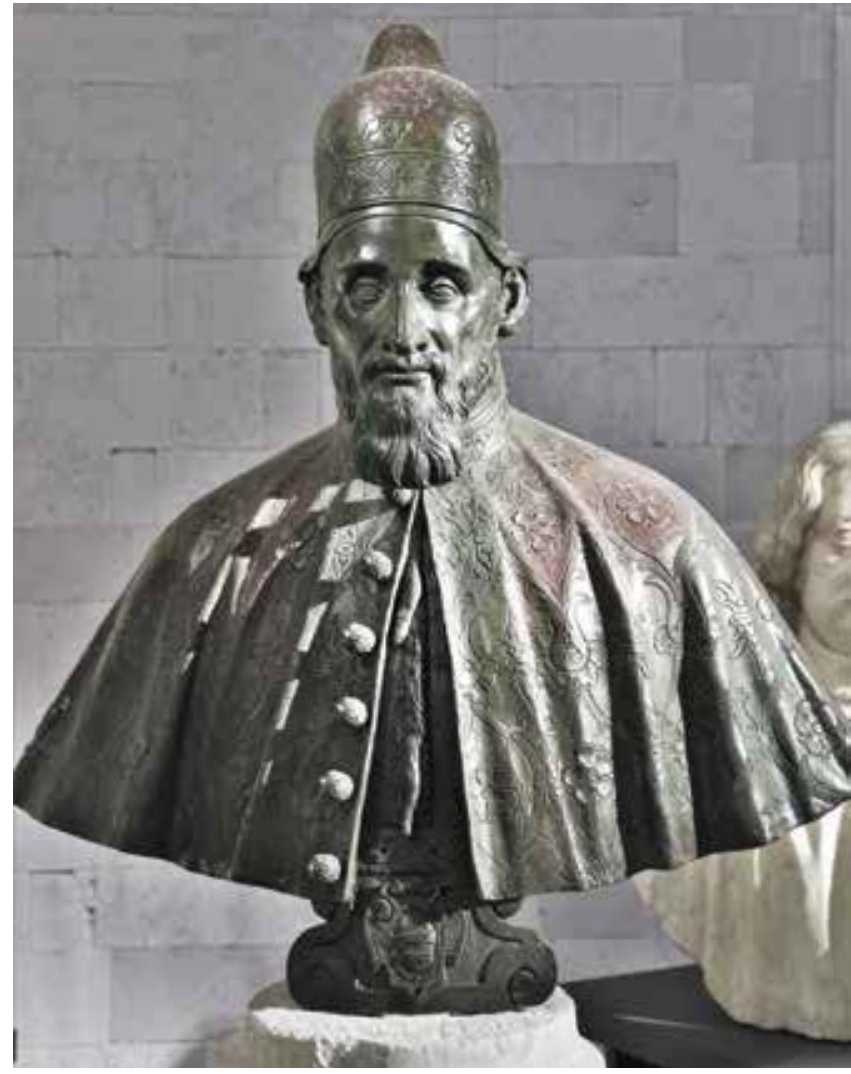

2. Workshop of Giulio del Moro, Doge Nicolò Donà, 1620, Regional Museum, Koper

Radionica Giulia del Mora, Dužd Nicolò Donà, 1620., Pokrajinski Muzej, Koper

decided to honour his memory in 1620 by making the bronze bust in the workshop of the famous Venetian sculptor, architect and painter Giulio del Moro..$^{12}$ The doge's bronze portrait is unique among the small number of busts of senior Venetian representatives in the eastern Adriatic region. ${ }^{13}$

From the archival documents we have learnt that on the main square of Šibenik there were three stone sculptures dedicated to general commanders of Dalmatia. ${ }^{14}$ The oldest was that of the provveditore Leonardo Foscolo, who served from 1645 to 1650; it was erected in 1647. Foscolo gained his reputation during the first years of the Cretan War (1645-1669) with several great victories against the Turks in the Dalmatian hinterland.${ }^{15}$ After he broke the Turkish siege of Šibenik in 1647, the Town Council decided to honour him with a statue. The artist was the Venetian stonecutter Andrea Galeazzo. He made Foscolo's statue out of stone from Korčula after his own design, for the price of 90 ducats. ${ }^{16}$ On the sculpture's pedestal the master chiselled an inscription in praise of Foscolo as the victor over the Turks. A few years later, in 1653, the Town Council ordered a second statue to honour the new provveditore, Lorenzo Dolfin. Again, Galeazzo executed the order. ${ }^{17}$ Unfortunately, Foscolo's and Dolfin's statues from Šibenik have not been preserved. Most likely, the lost statues looked like those preserved in the Town Museum of Split. ${ }^{18}$ They probably represent Leonardo Foscolo and come from various locations in Split. Finally, in 1681 the third statue, 


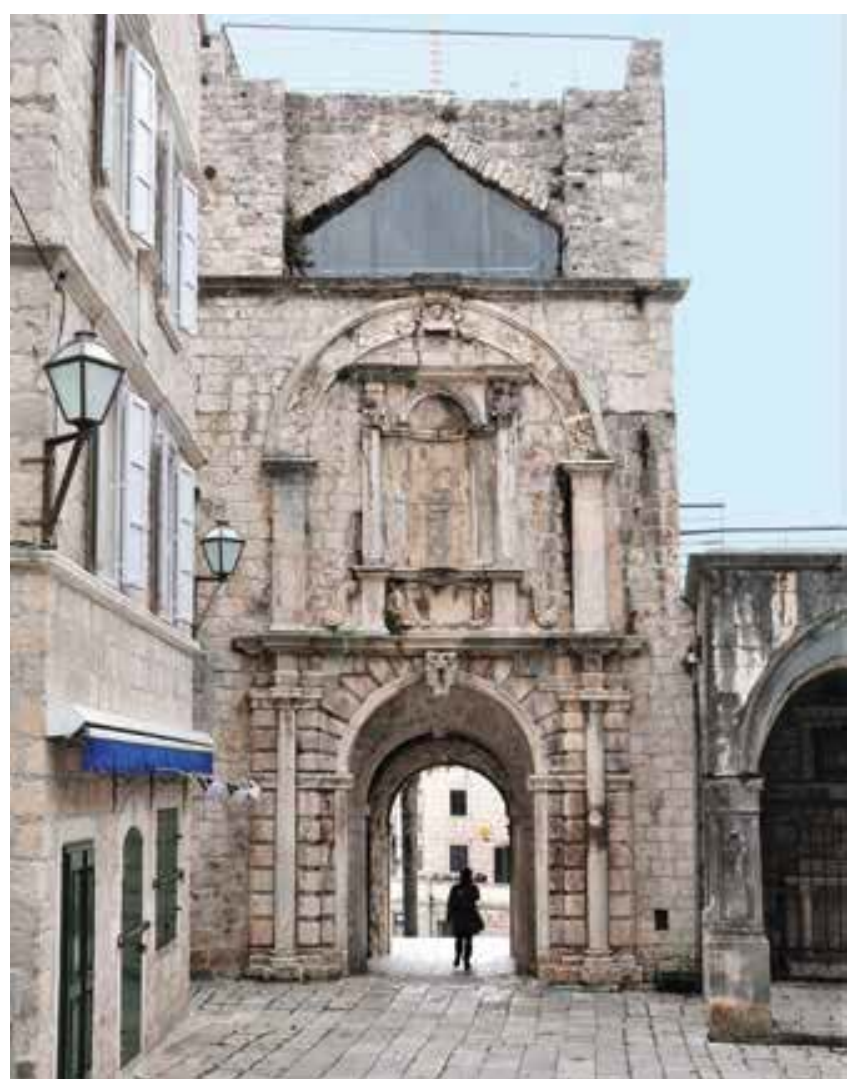

3. Triumphal arch dedicated to Leonardo Foscolo, Korčula, 1650 Slavoluk Leonarda Foscola, Korčula, 1650.

of the provveditore Girolamo Corner, was made for Šibenik's main square but, like the other two, it was lost. ${ }^{19}$

Unlike the freestanding statues of provveditores in Šibenik, the town of Korčula erected the greatest and the most complex public monument to honour a representative of the Venetian Republic. The Town Council and Korčulan nobleman commissioned a triumphal arch dedicated to Leonardo Foscolo in 1650 (Fig. 3). ${ }^{20}$ The arch occupies the rear side of a gothic tower, the main city entrance, and it faces the Town Hall square. Its lower part has an arched portal bearing the coat of arms of the Town of Korčula at the top. The upper section has a niche for the now missing sculpture, and beneath it there is an inscription in stone that praises Foscolo as "the victor over the Barbarians". A large arch filled with military trophies stands above the central niche. On the top of the arch once stood the Lion of Saint Mark holding Foscolo's coat of arms; unfortunately, it was destroyed in the Second World War. The original stone statue of Foscolo was removed, most probably after the Senate decision of 1691, and an effigy was stored in the Korčulan arsenal. ${ }^{22}$ In 1678 Jakov Arneri, a local nobleman, commissioned the stone statue of Leonardo Foscolo to be placed inside the niche in the courtyard of his family palace in Korčula (Fig. 4). ${ }^{23}$ The niche is made up of the fragments of a renaissance stone sink and the statue is awkwardly cut above its knees. Its right arm was broken and clumsily modified in order to hold a heart-shaped cartouche. The inscription in the cartouche mentions Foscolo and his servant Jacopo Arneri, who was in personal and military service under the great provveditore. ${ }^{24}$ The letters and the shape

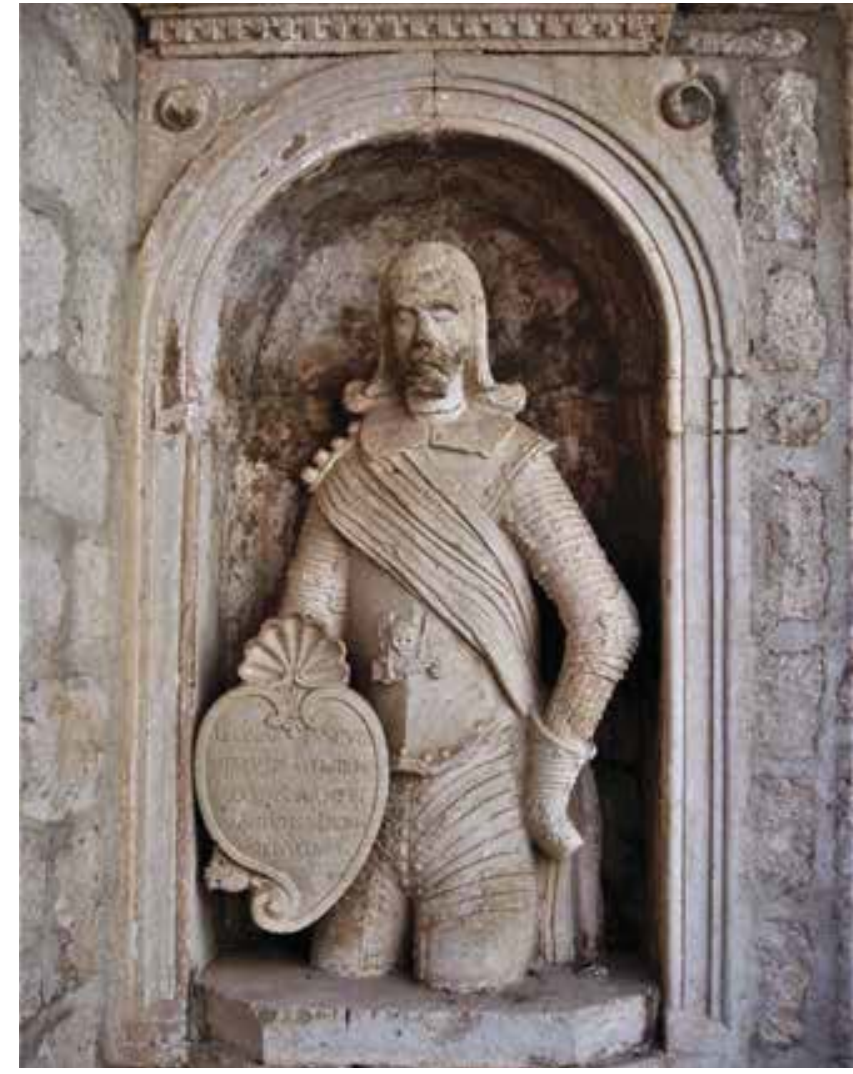

4. Leonardo Foscolo, courtyard of the Arneri Palace, Korčula Leonardo Foscolo, dvorište palače Arneri, Korčula

of the cartouche indicate that it was carved at the end of the $17^{\text {th }}$ century or the beginning of the $18^{\text {th }}$ century. It is obvious that Foscolo's statue has not been preserved in its original form. The proof is an unknown part of the statue itself, kept for centuries in the Arneri family. It is the stone fist of the missing right arm covered with armour in the shape of fish scales identical to the right fist on the Foscolo statue (Fig. 5). This means that the statue from Arneri's courtyard originally held a baston - the symbol of a military leader - in its right hand, and that the inscription was added latter. The modification of Foscolos statue may be seen as a tendency within local aristocratic families to glorify their members, but also to exaggerate their connections with the great provveditore and the Venetian government.

A different public monument from those mentioned above is the one erected on the façade inside the Franciscan church in Šibenik. It is an almost unknown tomb monument of the Venetian military commander Girolamo Cecconi, who died in 1642 (Fig. 6). The simple stone epitaph mentions his official duties in Cividale, Verona, the island of Crete, and Šibenik. ${ }^{25}$ His brother Giovanni Maria Cecconi, who married Catterina Orsini from Šibenik, and Girolamo's sister's nephew Fabrizio Beltrame, commissioned the monument. ${ }^{26}$ In the oval niche there is a clumsily carved torso wearing armour with a grotesque head of the deceased, topped by his coat of arms. Cecconi's tomb is, above all, a weak piece of sculpture. Nevertheless, it demonstrates very well the low standards of execution and stylistic simplicity of portrait busts during the middle years of the $17^{\text {th }}$ century in Dalmatia. 


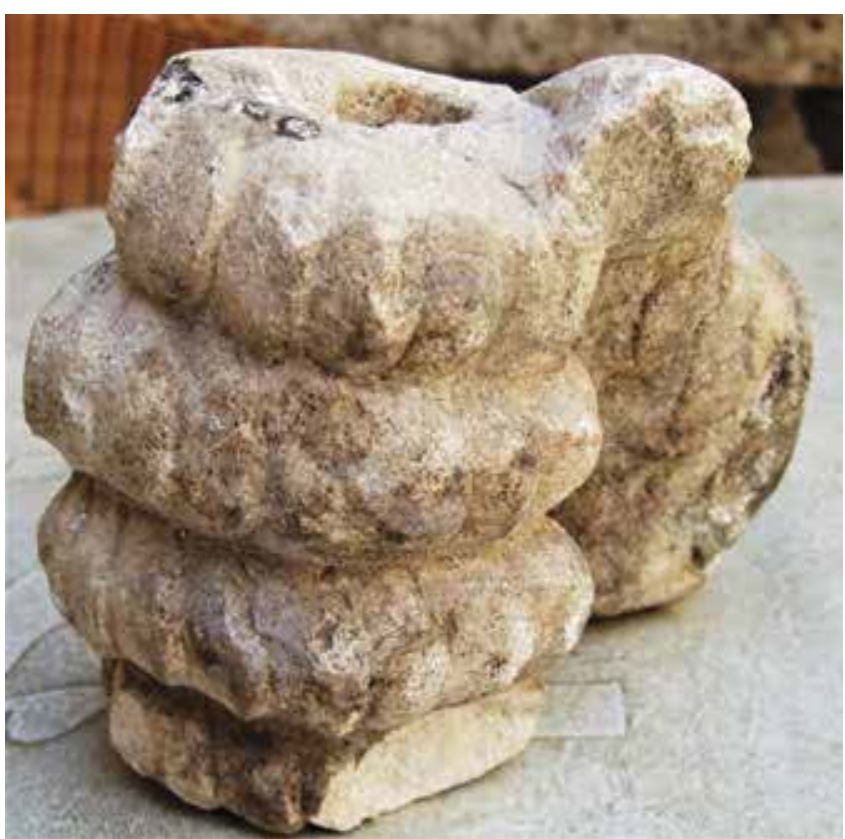

5. Original right fist of the Foscolo statue owned by the Arneri family, Korčula

Izvorna desna šaka Foscolovog kipa u posjedu obitelji Arneri, Korčula

Architectonic composition and decoration of tomb monuments in Dalmatia and Istria changed during the second half of the $17^{\text {th }}$ century. High-quality marble replaced the stone that had for centuries served as the basic material for local sculptors. Eastern Adriatic commissioners now began ordering designs, marble sculptures and portrait busts directly from Venice. Highquality sculpture was being shipped from the Venetian Lagoon and placed in Dalmatian and Istrian churches.

The earliest example of new kind of tomb monument could be found in the ex-Benedictine Church of Saint Chrysogonus in Zadar (Fig. 7). It is a monument to the provveditore Marino Zorzi, who died in 1675, just three months after arriving in Dalmatia. ${ }^{27}$ The monument is placed above the lateral door of the southern church nave. The position was chosen in order to make the inscription and provveditore's bust the last thing the visitors would see before leaving the church. The Zorzi monument is entirely made of various types of marble. A richly decorated cartouche bears Zorzi's coat of arms topped by the provveditore's hat. The commemorative inscription recalls his great career ${ }^{28} \mathrm{He}$ had a diplomatic mission at the court of the Spanish king Philipp IV, and at the court of the Habsburg emperor Leopold I. He also served as podestà of Padua and Belluno. Above the cartouche there is a circular niche of red marble flanked by military trophies: canons, war banners, spears and arrows. In the niche there is an "al naturale" portrait bust of the forty-three-year-old Marino Zorzi in armour with a cope and beautifully carved lace around his neck. His serene face was probably carved after a drawing or unknown oil portrait.

From the inscription on the epitaph we know that Marino's family was responsible for making this monument, primarily his brother, Marino Giovanni Zorzi, who since 1664 was the bishop of Brescia. He died in 1678, so the provveditore's

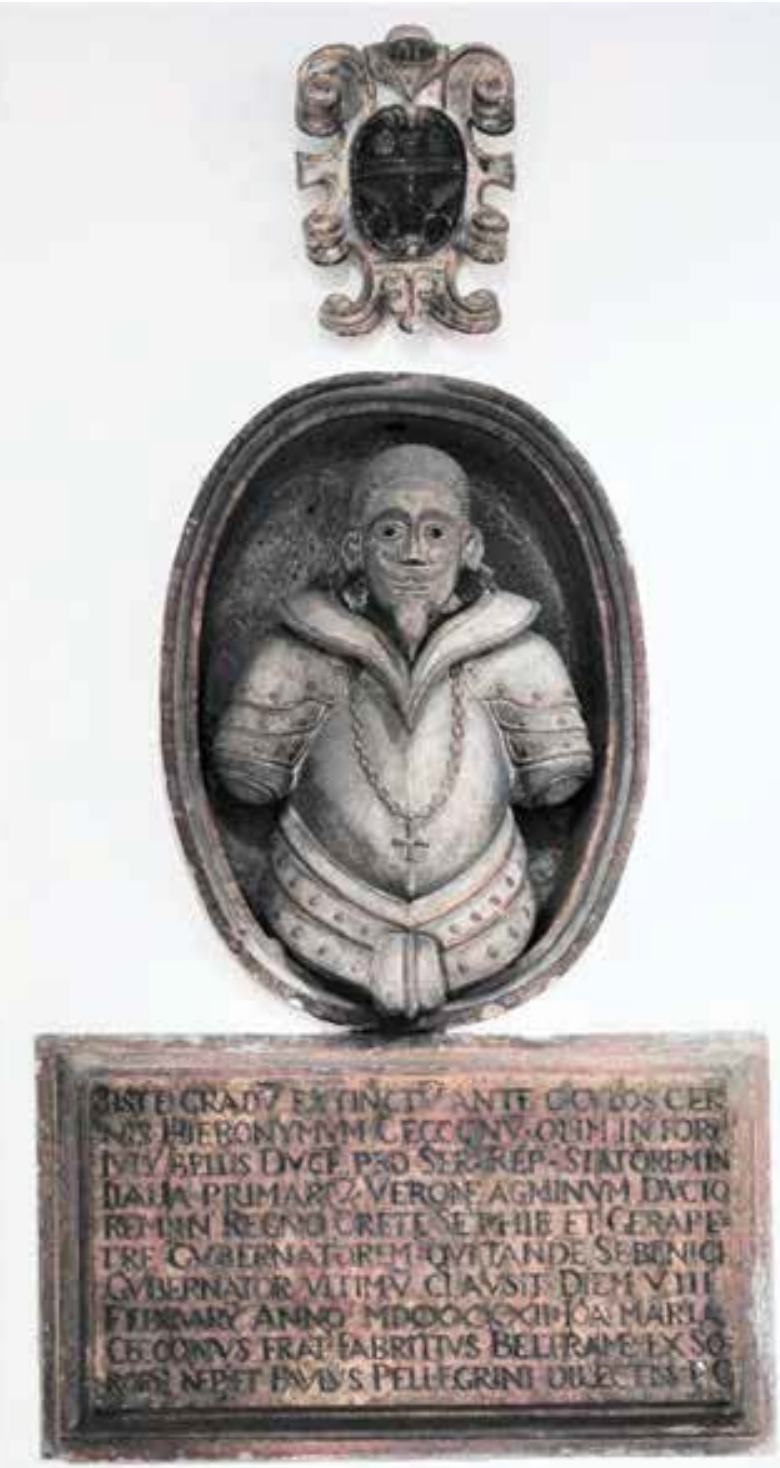

6. Monument to Girolamo Cecconi, Franciscan Church, Šibenik, 1642 Spomenik Girolamu Cecconiju, Franjevačka crkva, Šibenik, 1642.

monument in Zadar was probably finished prior to that date. Until now the typology of the Zorzi monument was connected with that of Bartolomeo Cargnoni, made by the sculptor Bernardo Falconi in 1664 for the Venetian church of Santa Maria dei Derelitti. ${ }^{29}$ Still, the Zadar monument is closer to those erected in honour of local military captains on the public buildings in the central square in Marano Lagunare, a town between Portogruaro and Grado. ${ }^{30}$ Of particular interest is the monument built in 1674 to the captain Zacharia Bernardo positioned on the façade of the Palazzo dei Provveditori (Fig. 8). We can see a similar cartouche, a coat of arms and military trophies topped with a marble bust. Dating to the same decade as the monument from Zadar are the three other Marano Lagunare monuments to captains Vicezo Bragadin from 1673, Giovanni Battista Bernardo from 1676 and finally from 1677 that of Bernardino Contarini. ${ }^{31}$ The creator of the Zorzi monument in Zadar 


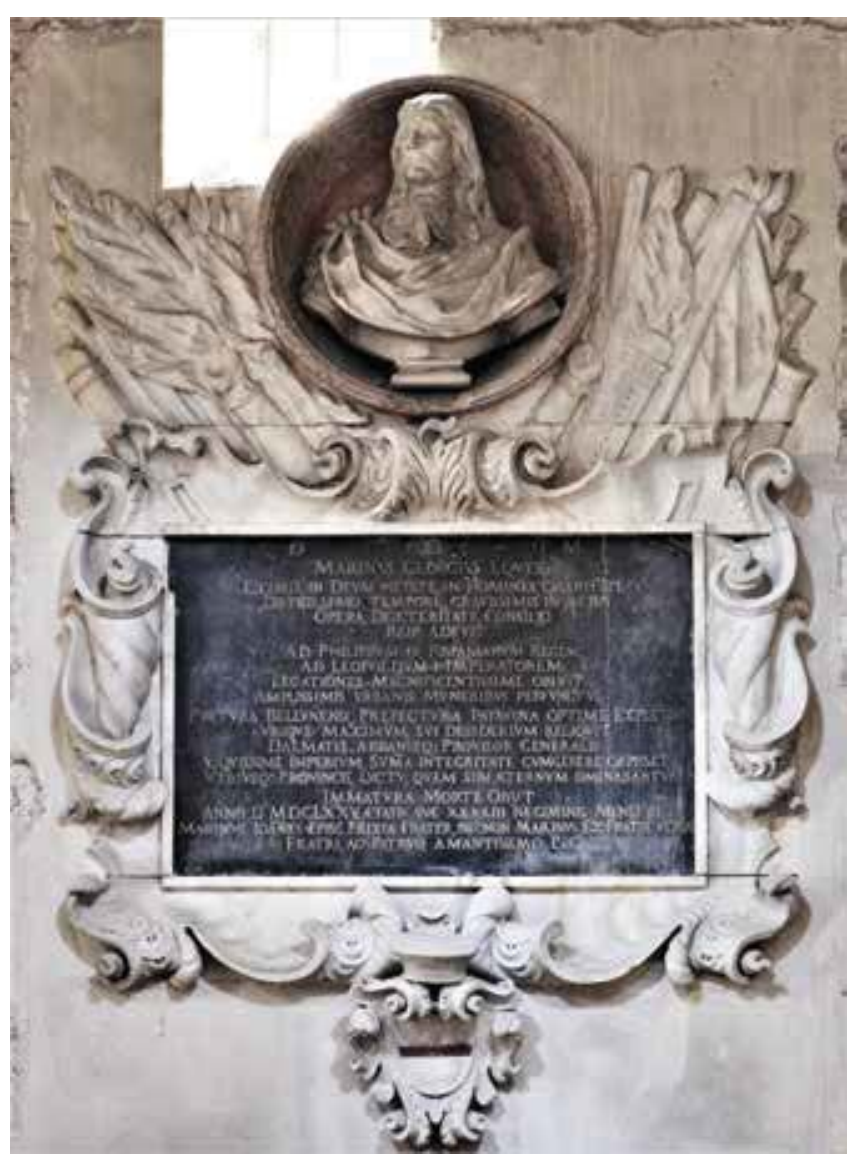

7. Monument to Marino Zorzi, Church of St Chrysogonus, Zadar, 1675

Spomenik Marinu Zorziju, Sveti Krševan, Zadar, 1675.

is still unknown and the marble bust shows them to be a skilful, but not a leading Venetian sculptor. Nevertheless, this monument brought a new tomb typology to the eastern Adriatic coast, and the bust of Marino Zorzi is the earliest existing example of a marble baroque portrait in Dalmatia.

From the archival documents we know that in the former church of Saint Donatus in Zadar there once stood a monument dedicated to Giustino da Riva, who was the provveditore from 1705 to $1707 .{ }^{32}$ It was made of marble and it was probably similar to the one dedicated to Marino Zorzi in Saint Chrysogonus's. Riva's monument erected in 1707 unfortunately disappeared 1798 when the church of Saint Donatus was desacralized.

The glorification of a local town or military commander become very popular in the Istrian capital of Koper only in the last quarter of the $17^{\text {th }}$ century. Four marble busts of local podestà with dedicatory inscriptions were placed by the local authorities on the façade of the Pretorian Palace. ${ }^{33}$ They represent Pietro Loredan, Lorenzo Donato, Angelo Morosini and Arsenio Priuli. These busts continued a tradition that began in 1620 with a bronze bust of the doge Nicolò Donà placed above the main entrance. All four marble busts were made in Venice, but the one representing Arsenio Priuli, made in 1679, deserves particular attention (Fig. 9). It is one of the earliest works by the great sculptor Giovanni Bonaz-

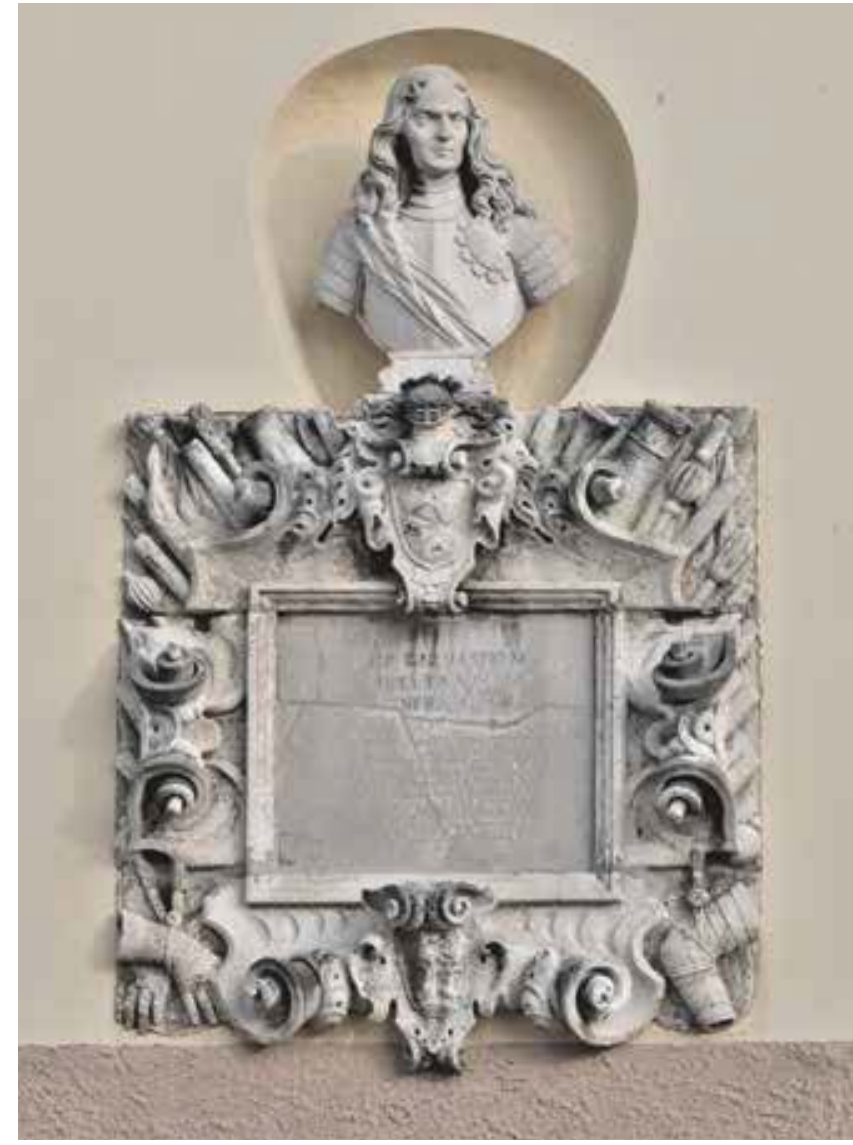

8. Monument to Zaccaria Bernardo, Pallazo dei Provveditori, Marano Lagunare, 1674

Spomenik Zaccariji Bernardu, Pallazo dei Provveditori, Marano Lagunare, 1674.

za. ${ }^{34}$ Podestà Priuli was responsible for erecting the new stone bridge and for repairing the public buildings and town walls. He is shown dressed in a tunic with a stole made of crimson velvet, a typical official uniform of senior Venetian state officers. Although the marble surface has been damaged by weather, Bonazza's bust is one of the most important examples of baroque portraiture in Istria and Dalmatia.

In Koper there are two other marble busts of podestà placed on the cathedral's façade. ${ }^{35}$ The bust of Giovanni Giustiniani was commissioned in 1684 by the grateful citizens of Koper. He prevented the spread of the plague in Koper and its environs. Placing a monument with a portrait bust of a military or a civil commander on religious buildings was quite unusual in Dalmatia and Istria. On the façade of the Cathedral of Hvar there are two empty niches, and under it two cartouches with erased inscriptions. Two busts of Venetian governors made by the master Ivan Pomenić in 1637 once stood inside the niches. ${ }^{36}$ An elaborate stone monument with an erased inscription and coat of arms stands on the façade of the Franciscan church in Šibenik. It was dedicated, probably in the mid- $18^{\text {th }}$ century, to the provveditore Francesco Grimani, whose bust once stood inside the stone niche. ${ }^{37}$ The only secular monument with an effigy on the church façade still standing is the one dedicated to a hero of the Morean War (1684 - 1699) 


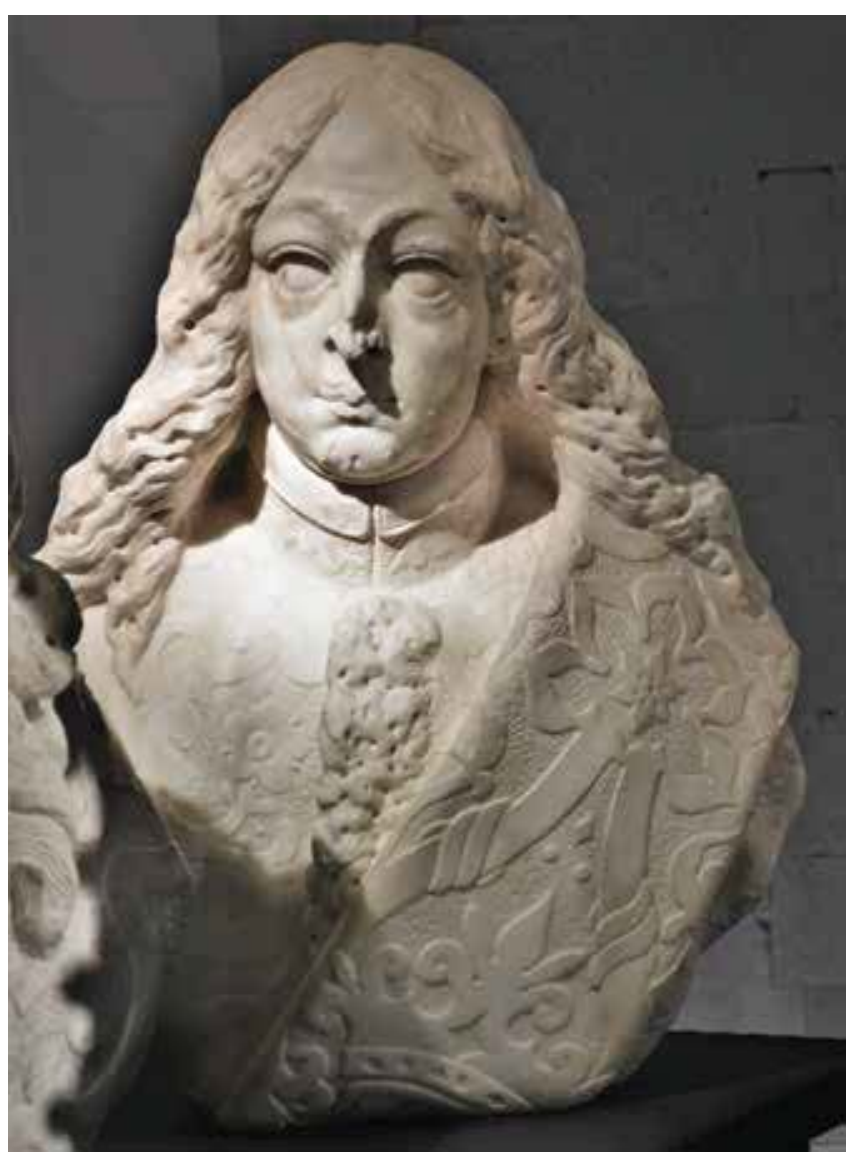

9. Giovanni Bonazza, Arsenio Priuli, 1679, Koper Regional Museum Giovanni Bonazza, Arsenio Priuli, 1679., Pokrajinski Muzej Koper

and Venetian senator, Antonio Bollani (Fig. 10). ${ }^{38}$ Since 1688, the monument has been situated on the facade of the parish church in Labin. During restoration work in the mid-19 $9^{\text {th }}$ century, many inscriptions, coats of arms and even the Saint Mark's lion were placed on the façade. The original position of the Bollani monument on the façade of the parish church is confirmed by the notes written by Bartolomeo Giorgini, a local physician. ${ }^{39}$ In 1731 , he wrote that the City Council placed the monument on the façade of the church because they wanted to celebrate the hero Bollani, whose mother, Bianca De Negri, was from an old noble family from Labin. The monument has the typical form of a commemorative military monument with a portrait bust. On the black marble slab, we can read about Bollani's great achievements. In 1686, immediately after the liberation of the fortress of Sinj from the Ottomans, he repaired the fortress walls and led an army against the Ottomans in the district of Zadar. ${ }^{40}$ Later, he became a Venetian senator. His portrait bust in armour was probably made by the Venetian sculptor Paolo Callalo. ${ }^{41}$ By building this monument to the still-living hero, the town of Labin wanted to show its connections with a celebrated person, originally from this small but important Istrian town.

In the Cathedral of Koper, the most magnificent baroque monument dedicated to the members of one prominent family was built in 1696. Local aristocrats from the Brutti

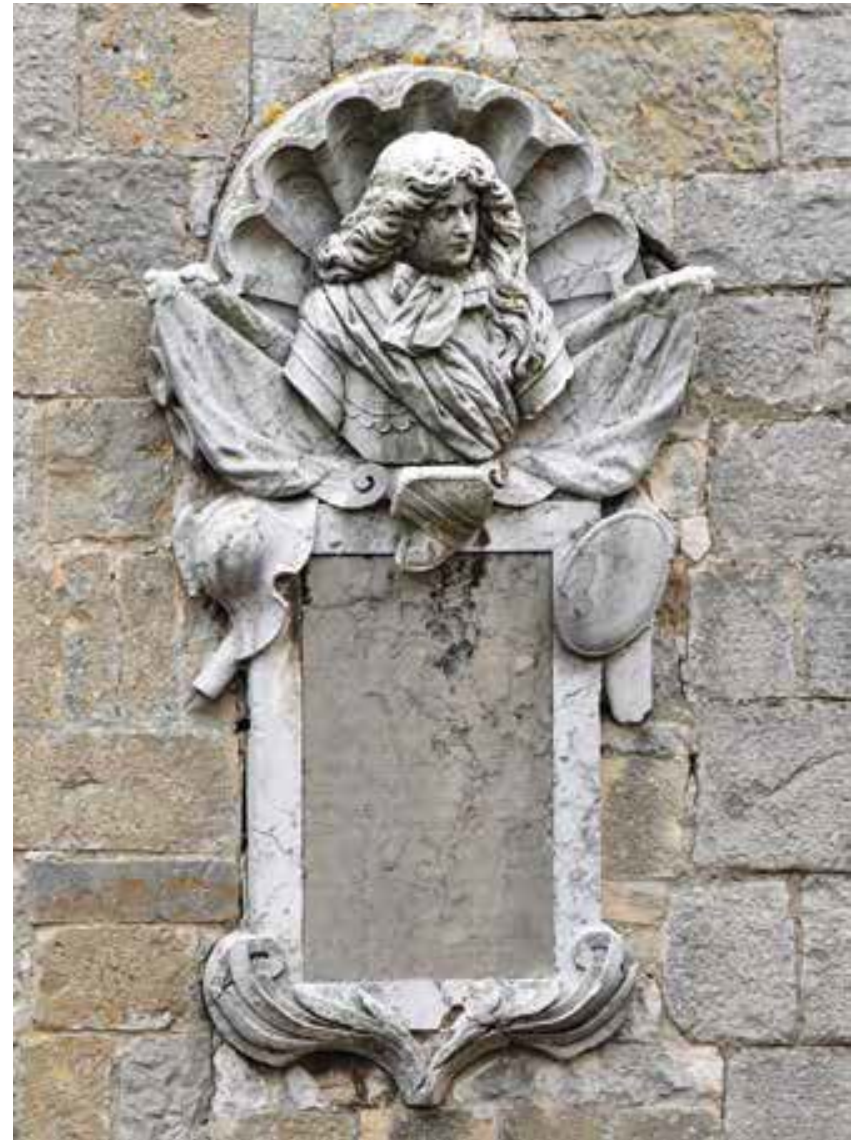

10. Monument to Antonio Bollani, 1688, Parish Church, Labin Spomenik Antoniju Bollaniju, 1688., župna crkva, Labin

family made their monument above the lateral door of the southern nave of the church (Fig. 11). In the centre of a sober architectonic frame on the black marble slab above the family's coat of arms we can read that Dionisio, Marco and Cristoforo made this monument to the eternal glory of their father, uncle and grandfather. ${ }^{42}$ The marble bust of Barnaba Brutti, who died in 1660, occupies the central position in front of the black pyramid. He served as a Venetian dragoman in Constantinople, which means that he was an interpreter of the Arabic language. For his service to the Republic, he was created a Knight of Saint Mark in $1619 .^{43}$ Therefore, on the marble bust there is a golden chain with the pendant cross of a Cavaliere di San Marco. On the left side there is a bust of Barnaba's son, Giacomo Brutti. He was Bishop of Novigrad in Istria from 1671 until his death in 1679. Giacomo wears a bishop's mozzetta, and above his head, there are ecclesiastic insignia: a chalice, a crosier, a mitre and a prelate's hat. To his left there is a personification of Cristian Charity symbolising Giacomo's service as merciful father and good shepherd to his diocese. On the right side of the pyramid there is a bust of Antonio Brutti, Barnaba's son and Giacomo's brother. He was the captain of the town guard; therefore, he is dressed in armour and is accompanied by military trophies: a shield, a helmet and a sabre hang above his head. To the right of Antonio's bust there is a personification of Strength, the virtue that is so desirable for military service. The beauty of the Koper 


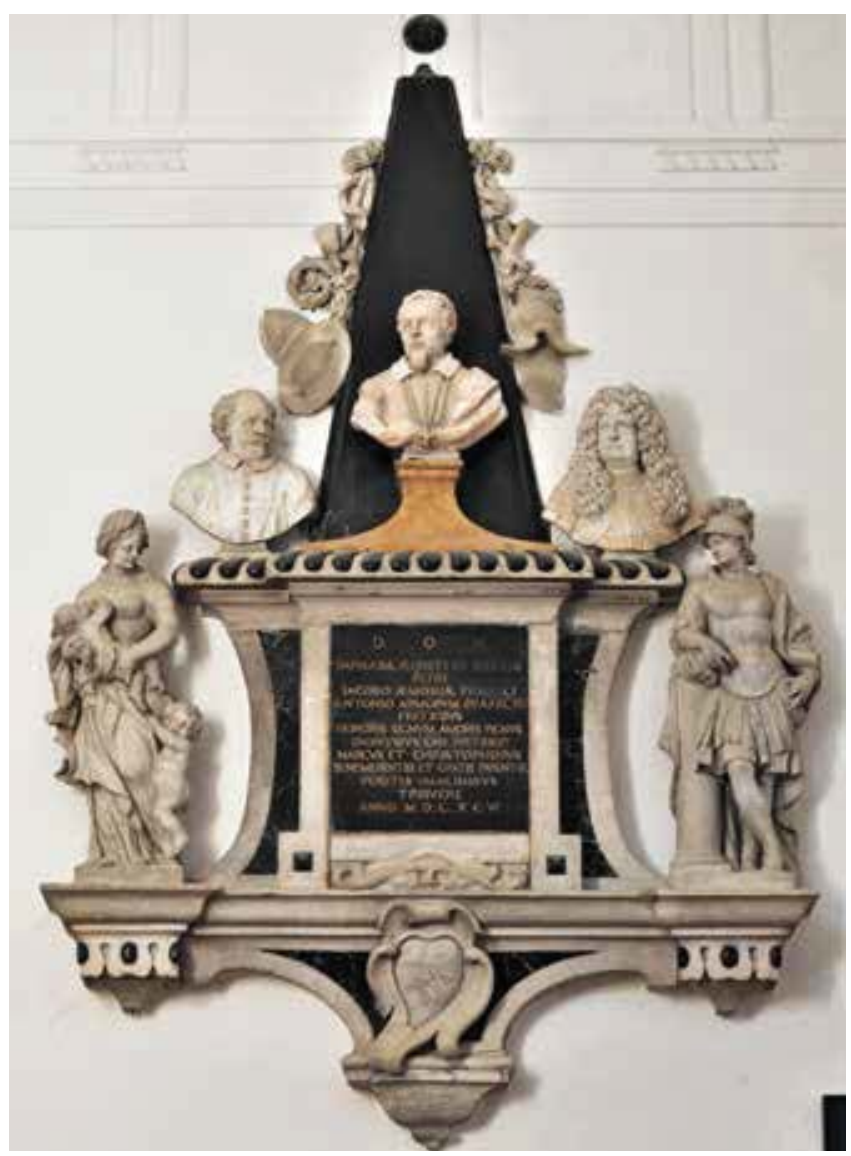

11. Monument to the Brutti Family, 1695, Cathedral, Koper Spomenik obitelji Brutti, 1695., Katedrala, Koper

monument lies in the fact that it is a unique example of a baroque commemorative concetto in Istria and Dalmatia where marble personifications, in this case Charity and Strength, embody the true virtues of the Brutti family. The architect of the monument is still unknown but he was certainly familiar with similar funeral and commemorative monuments in Venice and Padua. For instance, the Koper monument can be compared to the central part of the Girolamo Cavazza monument by Giuseppe Sardi from 1657 in the Venetian church of Madonna del Orto (Fig. 12). There are two personifications of virtue flanking a black pyramid topped with Cavazza’s bust. The tall pyramid with the busts of Pietro and Domenico Marchetti and the three statues of personification can still be seen on the grandiose monument of the Marchetti brothers made by Giovanni Comin in 1690 in the Saint Anthony Basilica in Padua and similar documented but unfortunately lost monuments built by Comin for the Tonon family in the Venetian church of Santa Maria Formosa. ${ }^{44}$ The sculptural decoration of the Koper monument was ascribed to the Venetian master Giuseppe Torretti and his workshop. ${ }^{45}$ The Brutti monument celebrates the idea of a dynastic glorification by representing three generations of the same family. We can see the same idea of this very popular Venetian concetto a little later on a few monuments inside Venetian churches. For example, two symmetrical monuments with four portrait busts of the Foscarini family were erected in the church of San Stae in 1711.

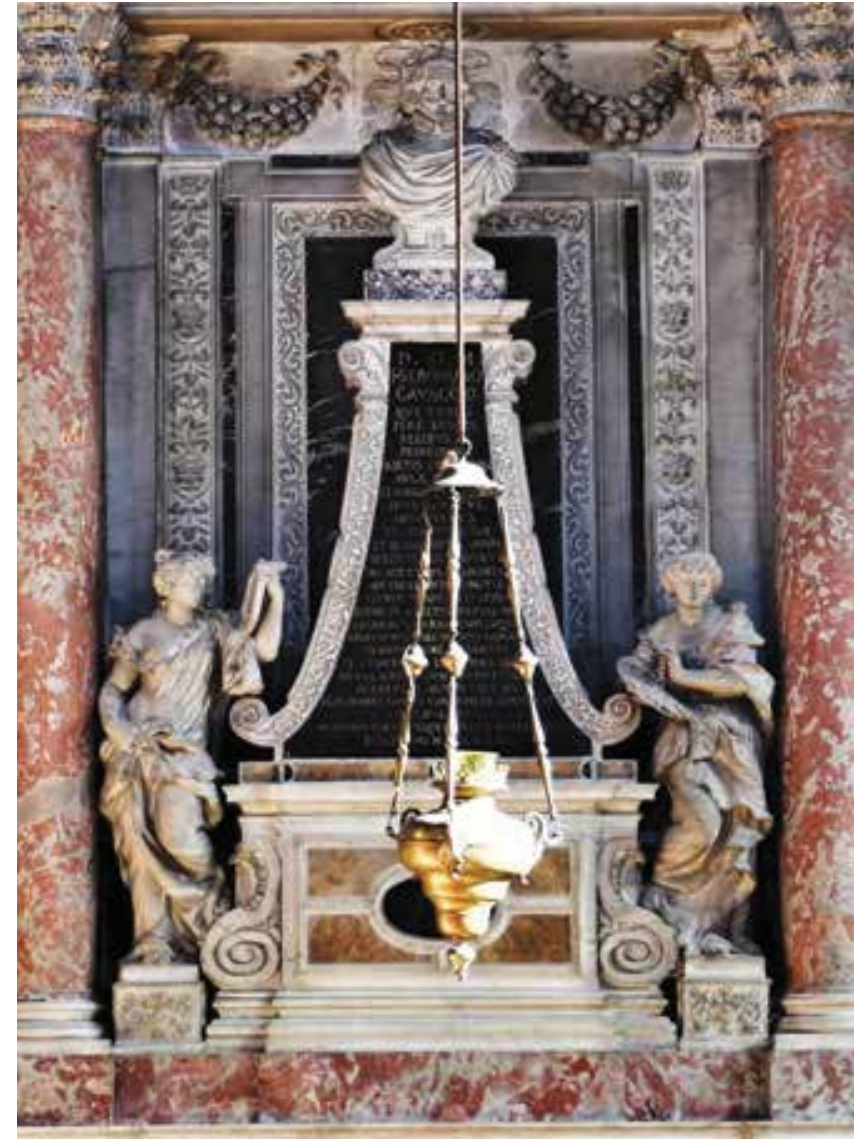

12. Giuseppe Sardi, The Monument to Girolamo Cavazza, 1657, detail, Madonna del Orto, Venice

Giuseppe Sardi, Spomenik Girolamu Cavazzi, 1657., detalj, Madonna del Orto, Venecija

In addition, there is the dynastic monument of the Cornaro family with ten portrait busts of ancestors commissioned by the doge Giovanni Cornaro in 1720 and placed in the family chapel in the church of San Nicolò dei Tolentini (Fig. 13). ${ }^{46}$

A few years later in Koper, we can find a commemorative bust of bishop Paolo Naldini (1686 - 1713), the well-known author of the Corografia Ecclesiastica, or a description of the City and Diocese of Koper. ${ }^{47} \mathrm{He}$ belonged to the Augustinian order and was responsible for the reconstruction of the city church of Saint Blaise with the monastery of Augustinian nuns. Therefore, in 1702 the grateful nuns made a monument to their benefactor, built on the side wall of the church (Fig. 14). It consists of a putto caring a dedicatory inscription on the base of a high pedestal, topped with the bishop's bust. It was made by an unknown Venetian sculptor, who probably used the print of Naldini's portrait from the Corografia, published a year before in Venice, as a model.

The last two examples of monuments with portrait busts can still be seen in Zadar. In the Benedictine Church of Saint Mary there is a monument to a Zadar nobleman, conte Simone Fanfogna (Fig. 15). ${ }^{48}$ He led the Venetian army in the Morean War in Dalmatia and the Levant. In 1696 he was promoted to the rank of higher military commander. During the War of the Spanish Succession he commanded over 8,000 soldiers 


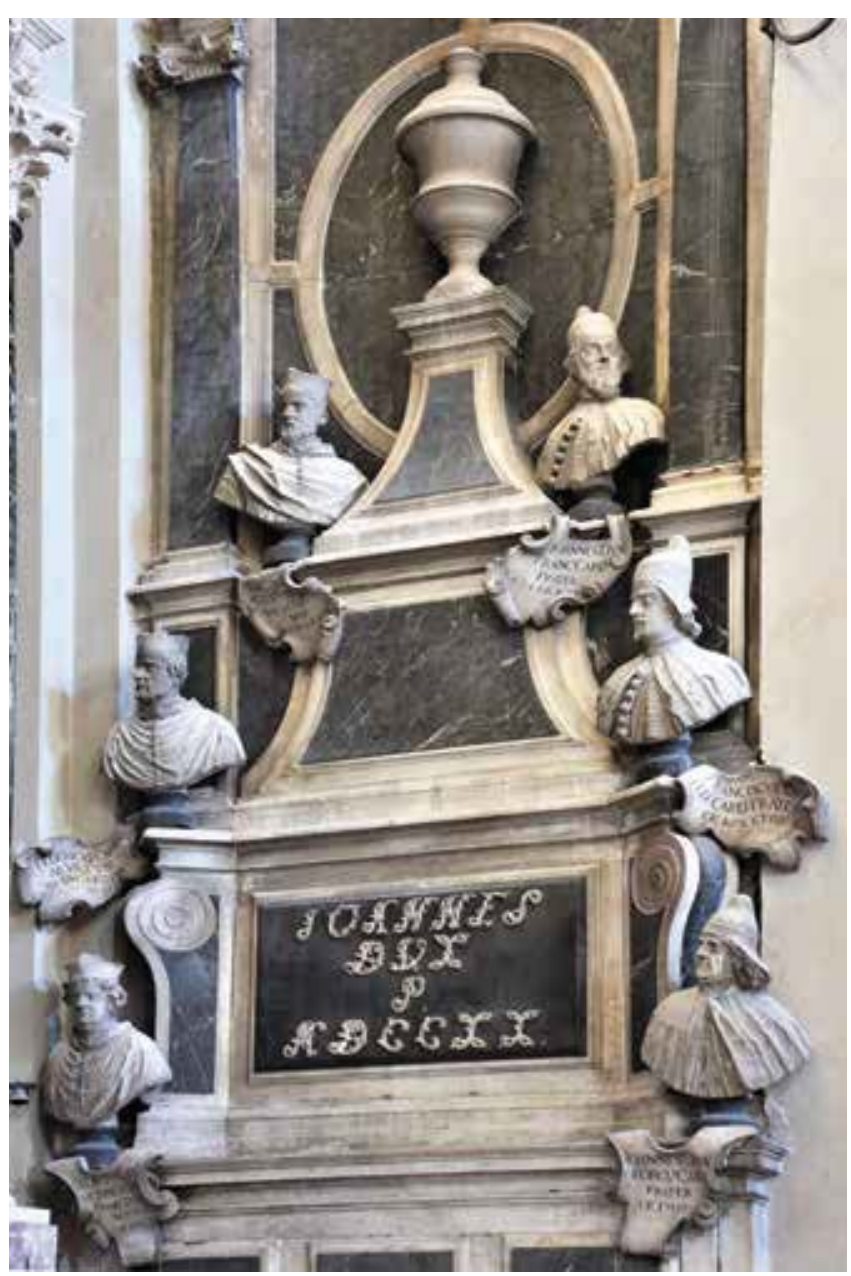

13. Monument to the Cornaro Family, 1720, San Nicolò dei Tolentini, Venice

Spomenik obitelji Cornaro, 1720., San Nicolò dei Tolentini, Venecija

in the region of Rovigo. In 1706 he became a general, but the next year he died of malaria in the town of Lendinara and was buried there in the Franciscan church. Two years later, in 1709, his remains were transferred to the Church of Saint Mary in Zadar. In the Church of Santa Sofia in Lendinara there is still a commemorative inscription dedicated to the general Fanfogna, whose embalmed heart remained in Veneto (Fig. 16) ${ }^{49}$ The members of his family built Simone's monument, but it has not been preserved in its original form. During the $19^{\text {th }}$ century the church was heavily restored. Afterwards, in 1856, the members of the Fanfogna family made a new commemorative inscription. They proudly declared that they were the successors of their great ancestor, the general and conte Simone Fanfogna. Simeone's idealised bust, with its great curly wig, is flanked by military trophies delicately carved in marble. The name of the sculptor, Alvise Tagliapietra, has been proposed as the creator of the Fanfogna bust..$^{50}$ An idealized head with a smooth and oval face and eyes wide open is more similar to the works of Venetian sculptors, the brothers Giuseppe and Paolo Groppelli. ${ }^{51}$

In 1764 , in the presbytery of the church dedicated to Saint Simon the Prophet, a lavish tomb monument was erected to Giovanni

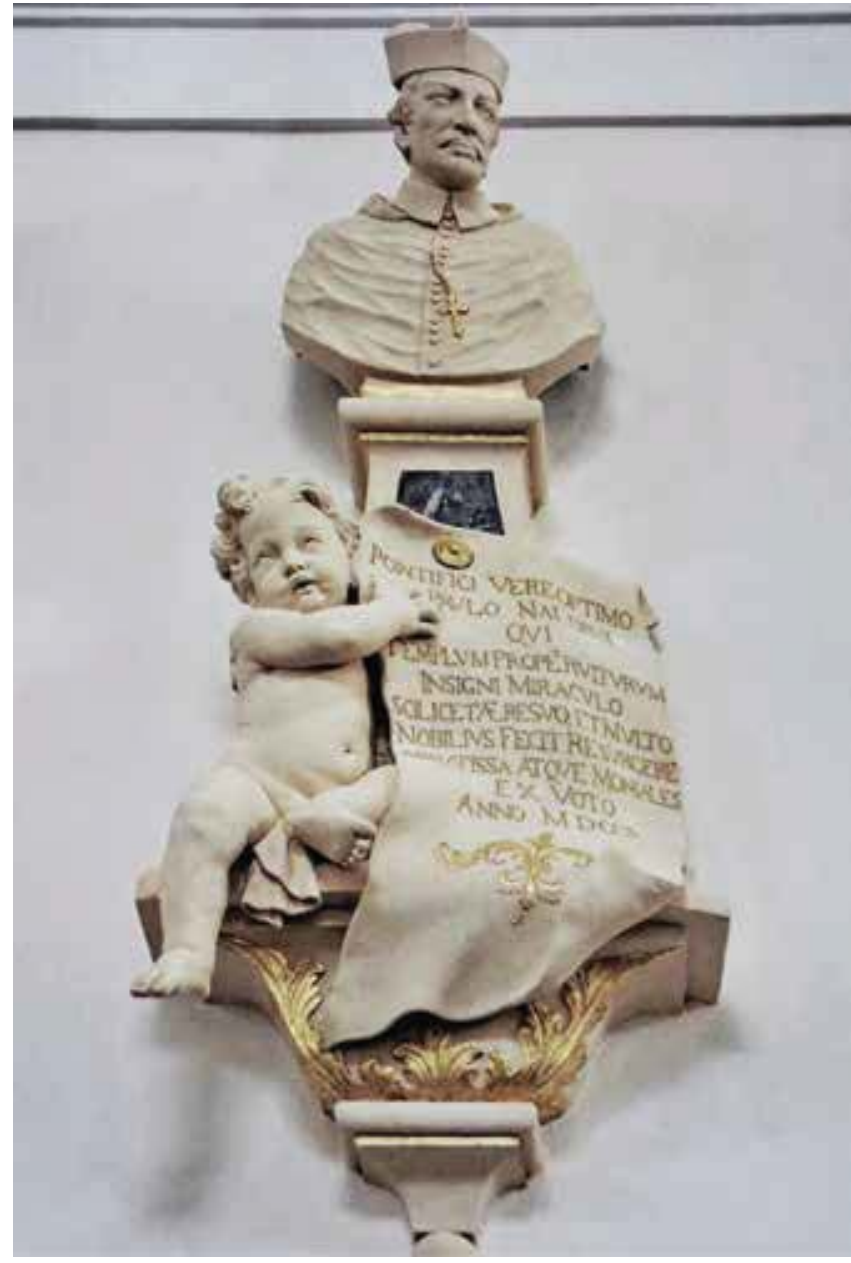

14. Monument to the bishop Paolo Naldini, 1702, Church of St Blaise, Koper

Spomenik biskupu Paolu Naldiniju, 1702., Sveti Blaž, Kopar

Francesco Rossini, who was a military engineer in the service of the Venetian Republic (Fig. 17). ${ }^{52}$ He served in Corfu, Brescia and Dalmatia. Rossini made a large number of designs and studies for reconstructions and improvements of fortresses in Dalmatia, especially for those in Knin, Sinj, Kotor and Zadar. ${ }^{53}$ A simple but solemn architectonic frame recalls altars built in the tradition of the famous Venetian Settecento architect Giorgio Massari. The quite precise sculptural decoration, the bust with trophies, as well as two small angels and Saint Simon the Prophet on the top of the monument, were all made by the famous Venetian sculptor Giovanni Maria Morlaiter. ${ }^{54}$ Surrounding the pedestal of Rossini's bust there are trophies connected to his military and engineering service: an orb, a compass, sheets of paper with fortress drawings, an angle quadrant, a level, books, a helmet and some war banners. Morlaiter's original first clay model of Rossini's bust still exists and is exhibited in the Museo del Settecento Veneziano in Ca' Rezzonico in Venice. ${ }^{55}$ Morlaiter carved Rossini's head with extraordinary skill and he achieved, above all, a vivid expression on the engineer's face. The sculptor probably used some unknown drawing of Rossini as a model for his marble portrait. The monument to Francesco Rossini represents the peak, but also the end of tomb monuments with marble busts in Dalmatia. 
Rad. Inst. povij. umjet. 43/2019. (139-150) Damir Tulić: Glory Crowned in Marble: Self-promotion of Individuals and Families in Seventeenth..

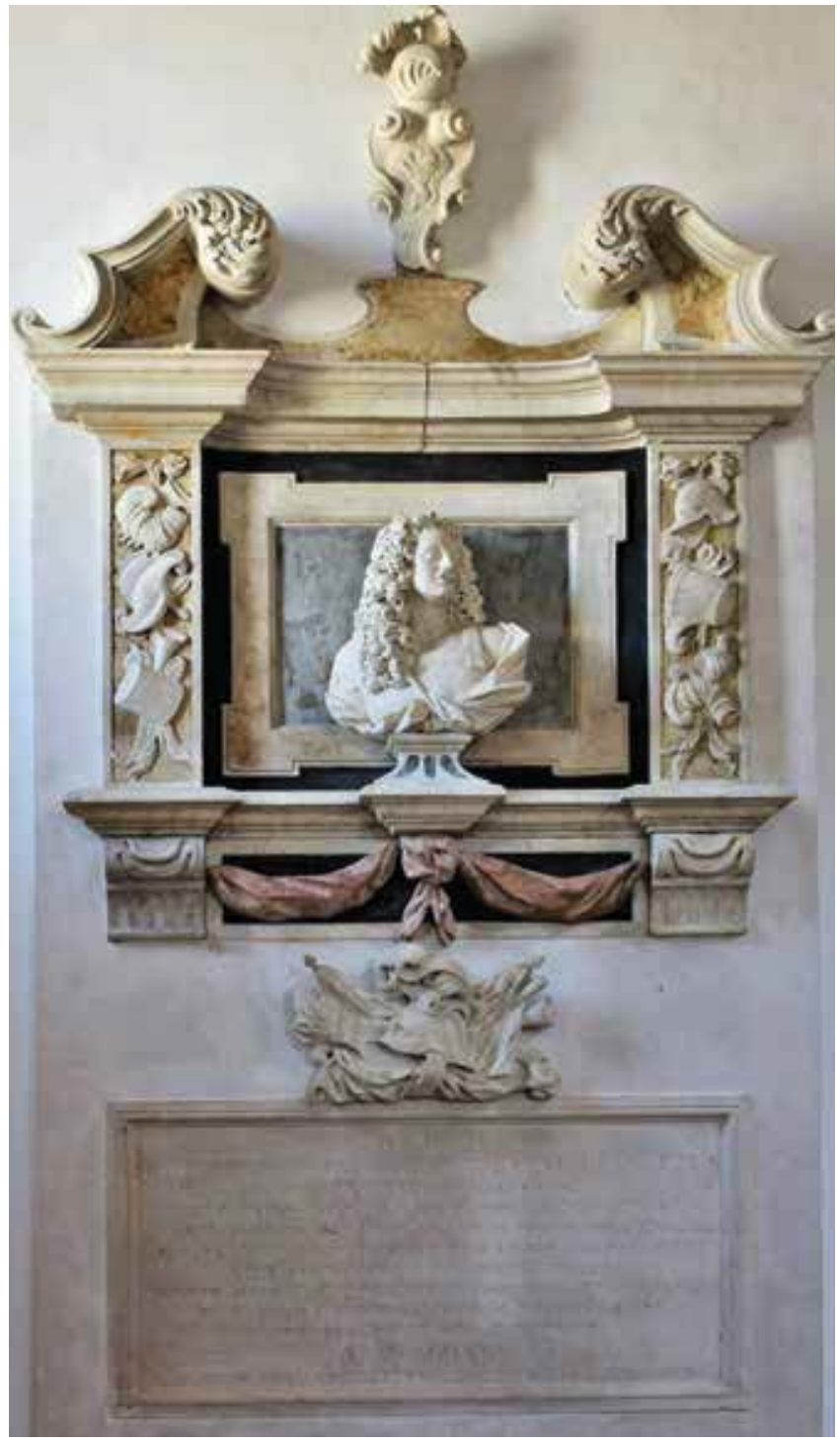

15. Monument to the Conte Simone Fanfogna, 1707 (1709 ?), St Mary's Church, Zadar

Spomenik conteu Simoneu Fanfogni, 1707. (1709. ?), Sveta Marija, Zadar

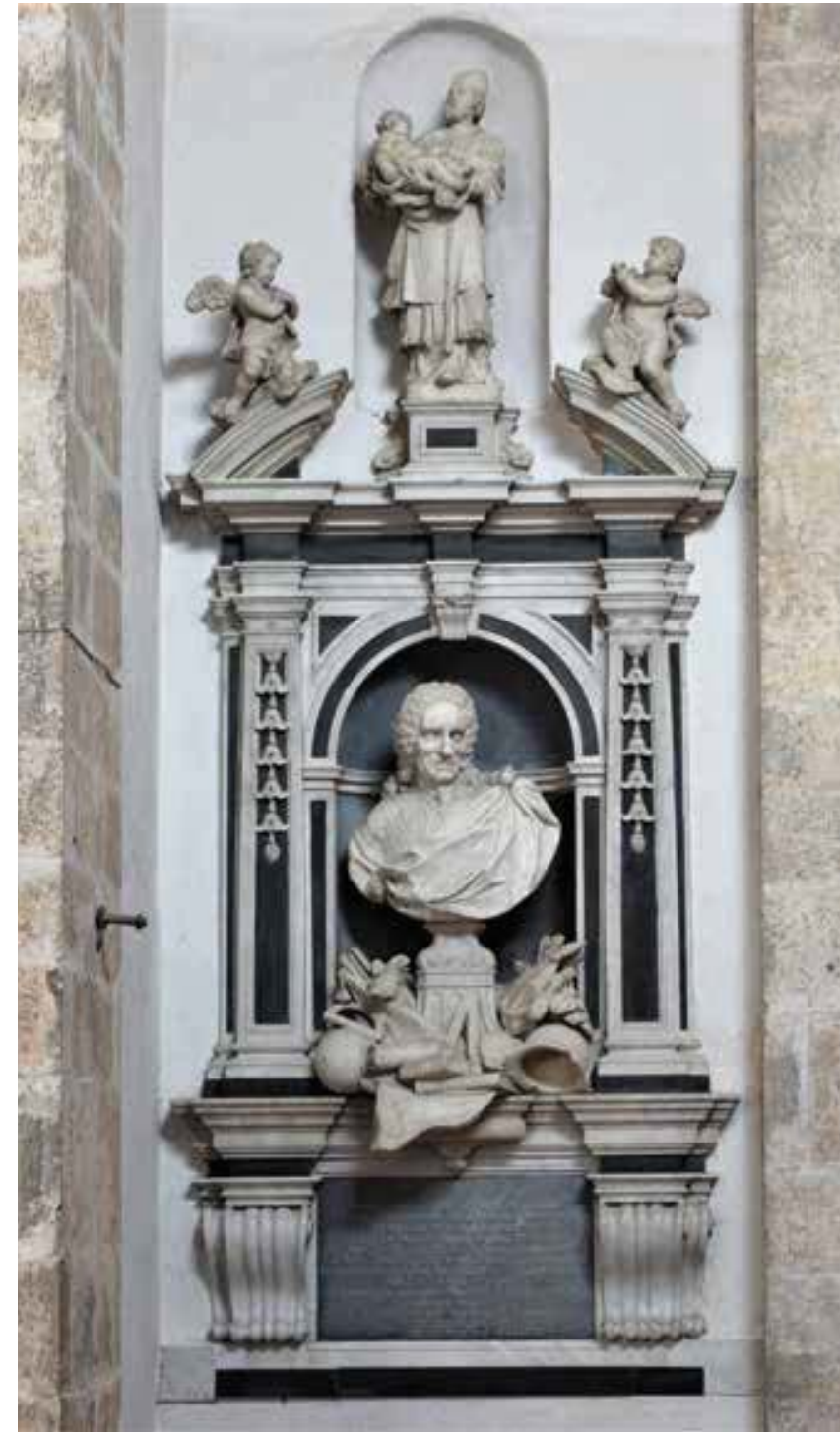

17. Monument to Giovanni Francesco Rossini, 1764, St Simeon's Church, Zadar

Spomenik Giovanniju Francescu Rossiniju, 1764., Sveti Šime, Zadar

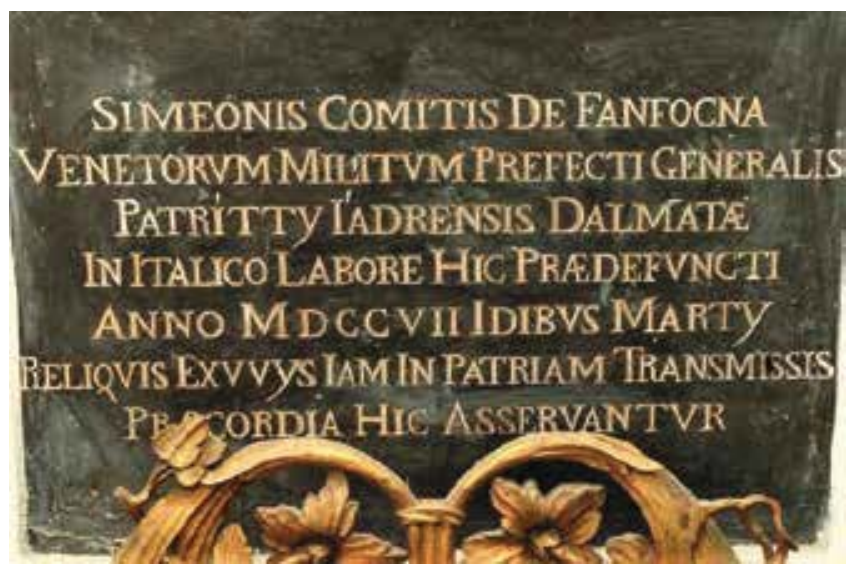

16. Commemorative inscription in honour of Simone Fanfogna, Santa Sofia, Lendinara

Komemorativna ploča u čast Simonea Fanfogne, Santa Sofia, Lendinara
All the aforementioned monuments with marble busts in Dalmatia and Istria were made to honour an important public person. In the stone sculptures of the still living provveditores and in the marble busts of the towns' podestà, we can see the expression of a grateful community that honours the merit of an individual. Their relatives usually commissioned the tomb monuments as permanent memories to a dead family member. In the case of the Brutti family in Koper Cathedral there is the idea of dynastic glorification by representing three generations of the same family. Finally, it is difficult to imagine that anybody in Dalmatia would have remembered, for example, the provveditore Marino Zorzi, who died just three months after arriving in Zadar. But his family conquered the past, as it were, by making the provveditore's luxurious monument with a portrait bust. Its everlasting fame was guaranteed by marble, the precious stone available in Venice, but only to the chosen ones. 


\section{Notes}

* This paper is an extended and elaborated version of work presented at the conference The Power of Media. Patronage, Representation and Propaganda in Early Modern Period (1450-1800) between the Mediterranean and Central Europe (Split, June 13-15, 2018).

** This work has been supported by Croatian Science Foundation under the project ET TIBI DABO: Commissions and Donors in Istria, Croatian Littoral and North Dalmatia from 1300 to 1800 (IP-2016-06-1265) and University of Rijeka under the project Barokna Rijeka (uniri-human-18-85 1219)

1

MASSIMO FAVILLA - RUGGERO RUGOLO, Venezia Barocca. Splendori e illusioni di un mondo in 'decadenza', Schio, 2009, 30-85. 2

MARTIN GAIER, Facciate sacre a scopo profano. Venezia e la polittica dei monumenti dal Quattrocento al Settecento, Venezia, 2002, 334-352, 540-550; MASSIMO FAVILLA - RUGGERO RUGOLO, Frammenti della Venezia Barocca, in: Atti dell'Istituto Veneto di Scienze, Lettere ed Arti, CLXIII (2004-2005), 69-86.

3

PAOLA ROSSI, La decorazione scultorea della facciata, Santa Maria dell Giglio, in: Il restauro della facciata, (ed.) Marina Fresa, Venezia, 1997, 15-39.

4

MASSIMO FAVILLA - RUGGERO RUGOLO (note 1), 37.

5

GABRIELLA DEL FRATE, Palmanova città-fortezza ideale, in: Arte in Friuli, Dal Quattrocento al Settecento, (ed.) Paolo Pasters, Udine, 2008, 143-151.

6

PAOLO GOI, Il Seicento e il Settecento, in: La Scultura nel Friuli Venezia Giulia II, Dal Quattrocento al Novecento, (ed.) Paolo Goi, Pordenone, 1988, 163; ANTONIO MANNO, Palma, La nuova Aquileia, specchio di Venezia e del Rinascimento, in: L'architettura militare di Venezia in Terraferma e in Adriatico fra XVI e XVII secolo, (ed.) Francesco Paolo Fiore, Firenze, 2014, 214-219.

7

"Labuso si conosce anche aggiustato espediente prescriverve essem pio e freno del avenire che in oltre preso di far levare tutte le statue intiere ed altre, che sopra base isolata si trovassero nelle piazze, cortigli, strade et in qualunque altro luogo delle città, fortczze, terre e castelli dello stato di terra e da mar, col rieponersi nei magazeni delle monitioni le figure ed i materiali da esser ivi custoditi, e che siano inoltre cancellate ed abollite tutte l'iscrizioni, che per ogni altra figura, ritratti o arma rimanessero, onde piu non sussista apparenza alcuna di questa memoria e tutto sia ridotto a semplice nudo ornarnento de palazzi consistendo senzaltra vana ostentazione il vero monumento nella bona impressione che trasecca nel cuore dei sudditi la detta giustizia de rapprresentati."; CVITO FISKOVIĆ, Izgled splitskog Narodnog trga u prošlosti, in: Peristil, 1 (1954), 87-88, n. 70; ANTONIO MANNO (note 6), 218; IGOR FISKOVIĆ, O primjerima damnatio memoriae iz hrvatske baštine, in: Prilozi Instituta za arheologiju u Zagrebu, 24 (2007), 495-497.

8

KRASANKA MAJER JURIŠIĆ, Arhitektura vlasti i suda. Vijećnice, lože i kneževe palače u Dalmaciji od 15. do 18. stoljeća, Zagreb, 2018, 124.

9

$<$ https://dubrovacki.slobodnadalmacija.hr/zupanija/korcula/clanak/id/604294/radovi-na-stoljetnoj-kuli-svih-svetih-pronaenedvije-kamene-biste-i-stepenice> (20 May 2019).
10

CVITO FISKOVIĆ, Urbanističko usavršavanje Korčule Kanavelićevog vremena [1973] in: Cvito Fisković, Korčulanske studije i eseji, (ed.) Vicko Fisković, Damir Tulić, Korčula, 2008, 298.

11

LARIS BORIĆ, Zadarsko poprsje providura Giangiacoma Zanea - prijedlog za Tripuna Bokanića, in: Radovi Instituta za povijest umjetnosti, 34 (2010), 91-100.

12

MASSIMO DE GRASSI, Busto di Nicolò Donà, in: Istria Città Maggiori. Capodistria, Parenzo, Pirano, Pola, Opere d'arte del Medioevo all'Ottocento, (ed.) Giuseppe Pavanello, Maria Walcher, Mariano del Friuli, 2001, 132-133.

13

KRUNO PRIJATELJ, Barok u Dalmaciji, in: ANĐELA HORVAT - RADMILA MATEJČIĆ - KRUNO PRIJATELJ, Barok u Hrvat$s k o j$, Zagreb, 1982, 782. According to its public display it could be compared only to the bronze bust of the benefactor Miho Pracat in the courtyard of the Rector's Palace in Dubrovnik, commissioned by the Senate of the Republic of Ragusa. It was made by Pier Paolo Jacometti from Recanati in 1638.

14

BOJAN GOJA, Andrea Galeazzo i spomenici generalnim providurima Leonardu Foscolu i Lorenzu Dolfinu u Šibeniku, in: Peristil, 60 (2017), 35-46 with the previous bibliography.

15

$<$ http://www.treccani.it/enciclopedia/leonardo-foscolo_(Dizionario-Biografico)/> (22 April 2019)

16

BOJAN GOJA (note 14), 42.

17 Ibid., 36.

18

CVITO FISKOVIĆ, Javni spomenici starijeg doba u Dalmaciji, in: Nova Doba, Split, 24 December 1939, 27-28.

19 BOJAN GOJA (note 14), 37.

20

CVITO FISKOVIĆ (note 10), 279-281; RADOVAN IVANČEVIĆ, Slavoluk Foscola (1650.) i maniristička komponenta u likovnoj baštini Korčule, in: Godišnjak grada Korčule, 3 (1998), 141-151.

21

DEVICTORI BARBARARX GENTIV ET INTER ORBIS / PRINCIPES - PROVIDENTISS.O/ LEONARDO FOSCOLO / PROC D · MARCI ILLIRIAE · ET · EPIRI · SUMO · PRAEF.TO / CIVES PATRITII BENEFICIIS · AVCTI PATRI, / ET NUMINI · MUNIFICENTISS.O ' TESSERA ' HANC · P., / TROPHAEO - AMPLIS.O PERPETVIS · AEVIS · LIBEN. / EX · INTIMIS · VOTIS · DICAT, ET - CONSACRA. / ANNO · A · PARTU · VIRGINIS · / MDCL

22

CVITO FISKOVIĆ (note 10), 280. During the archaeological excavations of All Saints Tower in the town of Korčula in the spring of 2019, a dozen fragments of life-size stone sculpture representing Venetian general were found. It is almost certain that these fragments belong to the original 1650 sculpture of Leonardo Foscolo once situated on the triumphal arch. 
23

CVITO FISKOVIĆ (note 10), 280. A full, life-sized statue of the provveditore Pietro Duodo once stood in the courtyard of the Bisanti Palace in Kotor. The stone effigy was made by the Kotor Town Council in 1691, but it was destroyed in the Second World War, CVITO FISKOVIĆ, Spomenička baština Boke Kotorske, (ed.) Radoslav Tomić, Zagreb, 2004, 97, 100.

24

LEONARD FVSCVL / VIRTVTIS EFFIGIEM / IACOBVS ARNERI / SERVITVTIS MEMORIA / NEPOTIBVS

25

SISTE GRADV. EXTINCTV. ANTE OCVLOS CER. / NIS HI-

ERONYMUVM CECCONV. 'OLIM IN FORI / IVLY BELLIS DVCE, PRO SER · REP · STATOREM IN / ITALIA PRIMARIV. - VERONAE AGMINVM DVCTO / REM · IN REGNO CRETE SETHIE ET GERAPE / TRE GVBERNATOREM · QVI TANDE SEBENICI / GVBERNATOR VLTIMV CLAVSIT DIEM VIII / FEBRVARY ANNO MDCXXXXII · IOA · MARIA / CECCONVS FRAT FABRITIVS BELTRAME EX SO- / RORE NEP ET PAVLVS PELLEGRINI DILECTISS · P C.

26

FEDERICO ANTONIO GALVANI, Il re d'armi di Sebenico, Venezia, 1884, 164.

27

CARLO FEDRICO BIANCHI, Zara Cristiana, vol. I, Zara, 1877, 306. RADOSLAV TOMIĆ, Barokni oltari i skulptura u Dalmaciji, Zagreb, 1995, 139-141, 202; RADOSLAV TOMIĆ, Umjetnička baština Zadarske nadbiskupije - Kiparstvo II, Zadar, 2008, 101-103.

28

CARLO FEDRICO BIANCHI (note 27), 306.

29

RADOSLAV TOMIĆ (note 27, 2008), 101-103.

30

RODOLFO DE GASPERI, Busti dei Rettori veneti nella Patria del Friul: la "Prima maniera" (1578-1620), in: Arte in Friuli arte a Trieste, 35 (2016), 51-55.

31

PAOLO GOI (note 6), 175-176.

32

CARLO FEDRICO BIANCHI (note 27), 388. According to Bianchi, the inscription on Riva's monument was:

JUSTINI A RIPA PIETAS IN MARMORE SURGIT / QVOD VIVENS TRIBVIT MORTVS HIC OPERIT.

33

GIUSEPPE CAPRIN, L'Istria Nobilissima, I, Trieste, 1905, 229231.

34

DAMIR TULIĆ, Alcune proposte per il catalogo giovanile di Giovanni Bonazza a Capodistria, Venezia e Padova e annotazioni per i suoi figli Francesco e Antonio, in: Ars Adriatica, 5 (2015), 146-147; DAMIR TULIĆ, Le opere dei Bonazza sulla costa orientale dell'Adriatico, in: Antonio Bonazza e la scultura veneta dell Settecento, (ed.) Carlo Cavalli, Andrea Nante, Verona, 2015, 45-47. 35

GIUSEPPE CAPRIN, L'Istria Nobilissima, II, Trieste, 1905, 193; MASSIMO DE GRASSI, Busto di Giovanni Giustinian, in: Istria Città Maggiori. Capodistria, Parenzo, Pirano, Pola, Opere d'arte del Medioevo all'Ottocento, (ed.) Giuseppe Pavanello, Maria Walcher, Mariano del Friuli, 2001, 61. On one of these two busts the dedicatory inscription has been erased.
36

CVITO FISKOVIĆ, Hvarska katedrala, Split, 1972, 82; VLADIMIR MARKOVIĆ, Pročelje hvarske katedrale, in: Renesansa i renesanse u umjetnosti Hrvatske. Zbornik radova sa znanstvenih skupova "Dani Cvita Fiskovića” održanih 2003. i 2004., (ed.) Predrag Marković, Jasenka Gudelj, Zagreb, 2008, 276-277.

37

JOŠKO BELAMARIĆ, Nepoznati spomenik Francescu Grimancu u Šibeniku, u: Vijenac, VII, 149, 18 November 1999, 15.

38

GIUSEPPE CAPRIN (note 35), 201-202; ANTONIO ALISI, Istria, Città minori, [1937], Trieste, 1997, 21.

39

BARTOLOMEO GIORGINI, Memorie istoriche della terra e teritorio d'Albona [1731], Labin, 2010, 73.

40

ISTORIA DELLA REPUBBLICA DI VENEZIA IN TEMPO DELLA SACRA LEGA CONTRA MAOMETTO IV., E TRE SUOI SUCCESSORI, GRAN SULTANI DE' TURCHI DI PIETRO GARZONI SENATORE. PARTE PRIMA. TERZA IMPRESSIONE. IN VENEZIA, APPRESSO GIOE MANFRÉ, MDCCXII., [1692], 169.

41

SIMONE GUERRIERO, Paolo Callalo. Un protagonista della scultura barocca a Venezia, in: Saggi e Memorie di Storia dell arte, 21 (1997), 49-50.

42

GIUSEPPE CAPRIN (note 35), 217-218.

43

GIOVANNI RADOSSI, Monumenta heraldica Iustinopolitana, Rovigno - Trieste, 2003, 105.

44

MASSIMO FAVILLA - RUGGERO RUGOLO, Le "deliranti fantasie" barocche di Giovanni Comin, Enrico Merengo, Antonio Molinari, Giacomo Piazzetta e Domenico Rossi, in: Saggi e Memorie di storia dell'arte, 40 (2016), 90-94.

45

MASSIMO DE GRASSI, Monumento Brutti, in: Istria Città Maggiori. Capodistria, Parenzo, Pirano, Pola, Opere d'arte del Medioevo all'Ottocento, (ed.) Giuseppe Pavanello, Maria Walcher, Mariano del Friuli, 2001, 60-61.

46

MASSIMO FAVILLA - RUGGERO RUGOLO, Gli scultori Giusto Le Court, Filippo Parodi, Giuseppe Torretti e Antonio Gai per i Corner: comitenze di una famiglia veneziana fra Sei e Settecento, in: Studi Trentini Arte, 91 (2012), 252-258.

47

VESNA KAMIN KAJFEŽ - GREGOR POBEŽIN, Koprski škof Paolo Naldini (1632 - 1713), njegova oporoka in njegovo zadnje počivališče v cerkvi sv. Blaža v Kopru, in: Zbornik za umetnostno zgodovino, n. v. XLVIII (2012), 67-80.

48

RADOSLAV TOMIĆ (note 27), 120-122 with the previous bibliography.

49

The marble commemorative slab originates from the Church of San Francesco, which was demolished in the $19^{\text {th }}$ century. It is now kept in the atrium of the Parish Church of Santa Sofia. The inscription reads: SIMEONIS COMITIS DE FANFOGA / VENETORVM MILITVM PREFECTI GENERALIS / PATRITTY IADRENSIS 
DALMATAE / IN ITALICO LABORE HIC PRAEDEFVNCTI / ANNO MDCCVII IDIBVS MARTY / RELIQVIS EXVVYS IAM IN PATRIAM TRANSMISSIS / PRAECORDIA HIC ASSERVANTVR.

50

RADOSLAV TOMIĆ (note 27), 122.

51

DAMIR TULIĆ, Nepoznati anđeli Giuseppea Groppellija u Zadru i nekadašnji oltar svete Stošije u Katedrali, in: Ars Adriatica, 6 (2016), 159.

52

RADOSLAV TOMIĆ (note 27), 180-184 with the previous bibliography.
53

DARKA BILIĆ, Inženjeri u službi Mletačke Republike. Inženjeri i civilna arhitektura u 18. stoljeću u mletačkoj Dalmaciji i Albaniji, Split, 2013, 250-254.

54

MONICA DE VINCENTI, Gian Maria Morlaiter e alcune sue opere giovanili in Istria e in Dalmazia, in: Francesco Robba and the Venetian Sculpture of the Eighteenth Century, (ed.) Janez Höfler, Ljubljana, 2000, 203-204.

55

MONICA DE VINCENTI, Storia del "fondo di bottega" di Giovanni Maria Morlaiter nel Museo del Settecento Veneziano di Ca' Rezzonico, in: Bollettino dei Musei Civici Veneziani, s. III, 6 (2011), 30-31.

\section{Sažetak}

\section{Damir Tulić}

\section{Slava okrunjena mramorom: Samopromocija osoba i obitelji na spomenicima 17. i 18. stoljeća u Istri i Dalmaciji}

Postavljanje spomenika uglednim članovima zajednice, posebno državnim i vojnim dužnosnicima, učestalo je u Veneciji te na njezinim posjedima Stato da Terra i Stato da Mar. Po uzoru na javne dužnosnike, brojni su privatni naručitelji ulagali velika novčana sredstva kako bi ime i djela zaslužnih članova obitelji ostala zauvijek zapamćena. Jedan od načina bilo je podizanje komemorativnih spomenika, ne nužno i nadgrobnih, na javnim mjestima ili u crkvama. Članovi venecijanske obitelji Barbaro financirali su 1679. godine gradnju pročelja venecijanske crkve Santa Maria del Giglio ukrašeno s pet velikih kipova braće Barbaro u prirodnoj veličini. Kipove i poprsja javnih dužnosnika, napose vojnih zapovjednika, podizali su gradovi kao izraz zahvale za dobrobit koje je slavljena osoba učinila na korist komune. Takvi su spomenici postavljeni u Zadru, Šibeniku, Splitu, Korčuli i Kotoru, a veći dio njih nije se sačuvao zbog odluke venecijanske vlasti iz 1691. godine kojom se naređuje uklanjanje takvih spomenika i natpisa kako bi se suzbilo glorificiranje pojedinaca i njihovih zasluga naspram Serenissime. Kip generalnog providura Leonarda Foscola postavljen u dvorište palače Arneri u Korčuli doživio je preinake kako bi se istaknule zasluge lokalne obitelji povezane uz toga visokog mletačkog dužnosnika. Mramorne biste gradskih knezova postavljaju se na komunalne palače u Kopru, ali i na crkvena pročelja, što je na istočnoj jadranskoj obali bio rijedak slučaj. Danas još jedino bista senatora Antonija Bollanija iz 1688. godine, junaka Morejskog rata (1684.-1699.) stoji na pročelju župne crkve u Labinu. Nadgrobni komemorativni spomenici kakav je, primjerice, onaj Girolama Cecconija iz 1642. godine u franjevačkoj crkvi u Šibeniku, isticali su zasluge pojedinca uz njegov u kamenu ovjekovječeni lik nadvišen obiteljskim grbom. U drugoj polovici 17. stoljeća mijenja se oblik komemorativnih grobnica kada se za njih $\mathrm{u}$ Veneciji naručuju portretne biste izrađene al naturale $\mathrm{u}$ mramoru. Takvih je nevelik broj, a prva među njima je ona providura Marina Zorzija iz 1675. crkvi svetog Krševana, potom ona contea Simonea Fanfogne iz 1707. godine $\mathrm{u}$ crkvi svete Marije te konačno komemorativna bista vojnog inženjera Francesca Rossinija u crkvi svetog Šime, također u Zadru. No najsloženiji i najveličanstveniji komemorativni spomenik jednog roda je onaj obitelji Brutti iz 1695. godine u koparskoj katedrali. Na njemu su tri mramorne biste članova obitelji, a popraćene su kipovima Ljubavi i Snage. Taj je spomenik jedini primjer složenijega baroknog concetta na istočnoj jadranskoj obali koji uključuje biste pokojnika i kipove personifikacija.

Može se zaključiti kako je kipove i biste živućih providura, gradskih kneževa te ratnih junaka postavljala zahvalna Komuna slaveći tako zasluge pojedinca učinjene na opću dobrobit. Drukčijeg karaktera su komemorativni, ne nužno i nadgrobni spomenici postavljeni u crkve. Njih je odreda podizala rodbina zbog vječne uspomene i zasluga svoga pokojnog člana, ali i u slavu obiteljskog imena. U slučaju obitelji Brutti u koparskoj katedrali može se govoriti o dinastičkoj glorifikaciji triju generacija iste obitelji po uzoru na venecijanske primjere. Naposljetku, teško je zamisliti da bi se itko sjećao, primjerice, providura Marina Zorzija koji je u četrdeset trećoj godini života te nakon samo tri mjeseca službe 1675. godine umro u Zadru. No njegova je rodbina 'pobijedila' vrijeme i zaborav postavivši mu spomenik s portretnom bistom izrađenom u skupocjenom mramoru, materijalu predviđenom za vječnost.

Ključne riječi: Dalmacija, Istra, Venecija, javni i nadgrobni spomenici, mramorne portretne biste, kamena skulptura, barok 


\section{Izvori ilustracija i autori fotografija / Sources of illustrations and photo Credits}

\begin{abstract}
Višnja Bralić
The Cult of Saint Euphemia, the Patron Saint of Rovinj, and the Venetian Politics of Co-creating Local Identities in Istrian Communities in the $15^{\text {th }}$ Century / Kult sv. Eufemije, zaštitnice Rovinja $i$ venecijanska politika sukreiranja lokalnih identiteta u istarskim zajednicama 15. stoljeća
\end{abstract}

1: (c) Museo Correr, Venezia (Giuseppe Rosaccio, Viaggio da Venezia a Costantinopoli, per mare e per Terra, \& insieme quello di Terra Santa, Venetia: Giacomo Franco, 1598, fol. 7v)

2-10: Ljubo Gamulin

\section{Anna Boreczky}

Historiography and Propaganda in the Royal Court of King Matthias: Hungarian Book Culture at the End of the Middle Ages and Beyond / Historiografija i propaganda na dvoru kralja Matije Korvina. Mađarska kultura knjige krajem srednjega vijeka i dalje

1-11, 14, 16-18: @ National Széchényi Library, Budapest (Országos Széchényi Könyvtár)

12, 13: ( ) Heidelberg University Library (Universitätsbibliothek Heidelberg)

15: From Wikimedia Commons, the free media repository

\section{Ivan Gerát}

Saint George Between Media and Functions / Sv. Juraj izmedu medija i funkija

1: Image courtesy National Gallery of Art, Washington DC

2: https://www.metmuseum.org/art/collection/, Public Domain

3: https://www.metmuseum.org/art/collection/, Public Domain

4, 5: Ivan Gerát

6: Archive of the Institute of Art History of the Slovak Academy of Sciences

\section{Ivan Ferenčak}

The Illustrations in the Glagolitic Books Printed by Bishop Šimun Kožičić Benja in Rijeka (1530-1531) / Ilustracije u glagoljskim knjigama biskupa Šimuna Kožičića Benje tiskanim u Rijeci (1530.-1531.)

1: Tamara Runjak, Rijetkosti u Knjižnici Hrvatske akademije znanosti i umjetnosti: katalog inkunabula i knjiga 16. stoljeća, Zagreb, 2011.

2, 7-10: Zagreb, Knjižnica Hrvatske akademije znanosti i umjetnosti, R-600, snimio Ivan Ferenčak 2019.

3: Ivan Ferenčak, 2019.

4: Biblioteca nazionale Marciana, Venezia, BM - Rari Ven. 579 (su concessione del Ministero per i Beni e le Attività Culturali - Biblioteca Nazionale Marciana. Divieto di riproduzione).

5: Biblioteca nazionale centrale di Firenze, Firenze, MAGL.2.1.109 (su concessione del Ministero dei beni e delle attività culturali. Biblioteca Nazionale Centrale di Firenze. Divieto di riproduzione)
6: Bibliothèque nationale de France, Paris, département Musique, RES-1527.

11: Nacionalna i sveučilišna knjižnica, Zagreb, RIIA- $8^{\circ}-8$.

12: Nacionalna i sveučilišna knjižnica, Zagreb, RIIA-16º-5.

\section{Milan Pelc}

Panegyric Emblem Books, Jesuits and the Habsburg Emperors: Some Examples Related to $17^{\text {th }}$-Century Croatia / Panegirički amblemi $i$ habsburški carevi - primjeri iz 17. stoljeća povezani s hrvatskom kulturnom sredinom

1: ๔ Hrvatski povijesni muzej, Zagreb / Croatian History Museum 2: ( University Library, Budapest / Egyetemi Könyvtár, Kézirattár 3-20: ๑ Austrian National Library, Vienna / Österreichische Nationalbibliothek

\section{Polona Vidmar}

Coesari in mis omni hora fidelis servivi: The Portraits of Sigismund Herberstein and Walter Leslie in Diplomatic Robes / Cæsari in mis omni hora fidelis servivi: Portreti Žigmunda Herbersteina $i$ Waltera Leslieja u diplomatskim odorama

1-2, 4, 6: Knjižnica Ivana Potrča Ptuj / Ivan Potrč Library Ptuj 3: Hollstein's German Engravings, Etchings and Woodcuts 1400-1700, vol. XIII A, 1984

5, 10, 13: Google Books

7-9, 11-12: Polona Vidmar

\section{Nóra G. Etényi}

Broadsheets with Engravings in a Manuscript Chronicle from Ulm: Visual Representations of the Hungarian Kingdom on German Political Leaflets during the War of Reconquest (1683-1699) / Grafički plakati u rukopisnoj kronici iz Ulma: Vizualna reprezentacija Ugarskog Kraljevstva na njemačkim političkim letcima tijekom Velikog turskog rata (1683.-1699.)

1, 4: (C) Austrian National Library Portrait Collection, Vienna / Österreichische Nationalbibliothek Porträtsammlung

2, 3, 6: @ Hungarian National Museum, Budapest / Magyar Nemzeti Múzeum

5, 7: @ National Széchényi Library, Budapest, Apponyi Sammlung / Országos Széchényi Könyvtár, Apponyi Metszet

\section{Werner Telesko}

Graphic prints of the Josephine period (1765/1790) and the propaganda of 'Religious Tolerance' / Grafički listovi Jozefinskog razdoblja (1765./1790.) i propaganda "Vjerske tolerancije"

1: ( ) Austrian National Library, Vienna

2: () Austrian National Library, Vienna

3: ㄷ Vienna Museum 
4: (C) Vienna Museum

5: (C) Vienna Museum

6: C Vienna Museum

\section{Martina Frank}

Representing the Republic in Seventeenth-Century Venice / Predstavljanje Republike u Veneciji 17. stoljeća

1, 3, 4, 5, 12: @ Austrian National Library, Vienna / Österreichische Nationalbibliothek

2, 15: Martina Frank

6: () University Library of Padua / Biblioteca universitaria di Padova

7: @ McNay Art Museum

8: Cat Bauer (https://venetiancat.blogspot.com/2016/11/thanksgiving-in-venice-celebrates-black.html)

9, 10: https://www.lamoneta.it/topic/157941-medaglia-nicol\% C3\%B2-contarini/

11: ๑ José Luiz Bernardes Ribeiro / CC BY-SA 4.0

13: Internet culturale

14: () Marciana National Library / Biblioteca Nazionale Marciana, Venezia

16: ( ) Museo Civico del Castello di San Giusto, Trieste

\section{Bálint Ugry - Maja Žvorc}

The Čakovec Stone Bust Collection: New Identifications, Possible Dating and the Identity of its Commissioner / Zbirka kamenih bisti u Čakovcu: Nove identifikacije, moguće datacije i naručitelj

1, 4, 6, 8, 10: Jovan Kliska

2: ๑ Austrian National Library (Österreichische Nationalbibliothek), Vienna

13, 15: ( ) Museum of Međimurje (Muzej Međimurja), Čakovec

3, 5, 7, 9, 11, 14, 16: Corpus Juris Hungarici, Tyrnaviae, 1751.

12: ( National Széchényi Library (Országos Széchényi Könyvtár), Budapest

17, 18: @ National Archives of Hungary (Magyar Nemzeti Levéltár), Budapest

19: Bálint Ugry

\section{Damir Tulić}

Glory Crowned in Marble: Self-promotion of Individuals and Families in Seventeenth- and Eighteenth-Century Monuments in Istria and Dalmatia / Slava okrunjena mramorom: Samopromocija osoba $i$ obitelji na spomenicima 17. i 18. stoljeća u Istri i Dalmaciji

1, 2, 3, 4, 5, 6, 7, 8, 9, 10, 11, 12, 13, 15, 16, 17: Damir Tulić

14: Samo Štefanac

\section{Jasminka Najcer Sabljak}

Portraits of Habsburg Rulers in the Aristocratic Collections of Eastern Croatia / Portreti vladara obitelji Habsburg u plemićkim zbirkama istočne Hrvatske

\author{
1, 2: ( $)$ Galerija Matice srpske, Novi Sad \\ 3: Francisca Clary-Aldringen \\ 4: Davor Šarić
}

\section{Danko Zelić}

Projekt Fausta Vrančića za opsadu Ostendea iz 1603. godine / Faust Vrančićs Design for the Siege of Ostend from the Year 1603

1: Matthias Dögen, Architectura militaris moderna (...), Amstelodami, 1647., 354-355.
2-4: ( ) Rijksarchief in België / Archives de l'État en Belgique, Algemeen Rijksarchief / Archives générales du Royaume, Fond Duitse Staatssecretarie / Secrétairerie d'État Allemande, 413, p. 309

5: Pompeo Giustiniano, Delle guerre di Fiandra libri 6. Di Pompeo Giustiniano del Consiglio di guerra di S. M. C. (...) Posti in luce da Gioseppe Gamurini (...) con le figure delle cose più notabili, In Anversa, 1609., 84-85

\section{Radoslav Tomić}

Generalni providur Leonardo Foscolo i umjetnost u Dalmaciji / Provveditore generale Leonardo Foscolo and Art in Dalmatia

1-30: Fotografije iz arhive autora

4: Presnimak iz: Alfons Pavich pl. Pfauenthal, Prinosi povijesti Poljica, Sarajevo, 1903., 79.

\section{Petar Puhmajer}

Dvorac Cernik - kontinuitet i mijene predturskog nasljeđa u barokno doba / The Cernik Castle - Continuity and Change in the Pre-Ottoman Heritage during the Baroque Era

1, 2, 9: Paolo Mofardin, Fototeka IPU

3 a, b; 6 a , b c c, d: arhitektonski snimak Sanja Štok i Barbara Kulmer, grafička obrada Marin Čalušić

4, 7, 10, 11: Petar Puhmajer

5: ๑ Generallandesarchiv, Karlsruhe

\section{Bojan Goja}

Kuća Cattinelli 1772. godine: prilog poznavanju stambene arhitekture u Zadru u 18. stoljeću /

The Cattinelli House in 1772: A Contribution to Our Knowledge of Housing Architecture in $18^{\text {th }}$-Century Zadar

1, 2: Bojan Goja

3, 4: Branko Maroević, dipl. ing. arh., izrada nacrta

\section{Iva Pasini Tržec}

Slike starih majstora iz zbirke Ervina i Branke Weiss u Strossmayerovoj galeriji u Zagrebu / Paintings of Old Masters from the Collection of Ervin and Branka Weiss in the Strossmayer Gallery in Zagreb

1, 3, 6: Arhiv Strossmayerove galerije HAZU, dokumentacija Weiss 2: MAK - Museum of Applied Arts (Museum für angewandte Kunst), Vienna

4: RKD - Netherlands Institute for Art History (Rijksbureau voor Kunsthistorische Documentatie), Den Haag

5: Palais Liechtenstein, Vienna

6: ( ) Strossmayerova galerija starih majstora HAZU

7: BDA - Bundesdenkmalamt Archiv (Federal Monuments Authority Austria Archive), Vienna

\section{Irena Kraševac}

Prva tri djela u fundusu Moderne galerije Društva umjetnosti / The First Three Artworks in the Holdings of the Modern Gallery of the Art Society in Zagreb

1, 4: Goran Vranić, Moderna galerija, Zagreb

2: Paolo Mofardin, Institut za povijest umjetnosti, Zagreb

3: digitalna presnimka iz kataloga izložbe: Ivan Meštrović. Skulpturen, Nationalgalerie, Staatliche Museen Preußischer Kulturbesitz, Berlin, 1987. (Nenad Gattin?)

5: Arhiv Galerije grada Praga / Archive of Prague City Gallery 